\title{
SURVEY
}

\section{Historians, Social Scientists, Servants, and Domestic Workers: Fifty Years of Research on Domestic and Care Work}

\author{
R A FFAELLA SARTI \\ Department of International Studies. History, Languages, Cultures \\ University of Urbino "Carlo Bo" \\ Piazza Rinascimento 7, 61029 Urbino PU, Italy \\ E-mail: raffaella.sarti@uniurb.it
}

\begin{abstract}
AвSTRACT: Historical research on domestic servants has a long tradition. Research, however, has become more systematic from the I960s onwards thanks to social historians, historians focusing on the family, historical demographers and (particularly from the 1970s) women's and gender historians. For a long time, scholars assumed that domestic service (especially by live-in workers) would decline, or even disappear, because of household modernization, social progress, and development of the welfare state. The (largely unexpected) "revival" of paid domestic and care work in the past three decades has prompted sociologists and other social scientists to focus on the theme, opening new opportunities for exchange between historians and social scientists. This article provides a review of the research on these issues at a global level, though with a focus on Europe and the (former) European colonies, over the past fifty years, illustrating the different approaches and their results.
\end{abstract}

\section{INTRODUCTION}

This article provides an overview of the research by historians and social scientists on domestic service over the past fifty years, ${ }^{\mathrm{I}}$ at times touching upon earlier research. It offers a global perspective, though the main focus

I. This survey is based on literature in Italian, English, French, German, Spanish, and Portuguese. It inevitably has some bias, therefore, due to my lack of knowledge of other languages. I generally use the word "servants" when I deal with a (rather) distant past, and the term "domestic workers" when I speak about more recent decades. A first version of this survey was presented at the International Conference of Labour and Social History (ITH), "Towards a Global History of Domestic Workers and Caregivers," Linz, I2-Is September 2013. I am grateful to the participants for their comments. 
is on research on Europe and, to a lesser extent, (former) European colonies. I will highlight those studies of domestic service which in my view have played a major role in stimulating further debate. Furthermore, I will illustrate the studies' different approaches and results, as well as those issues that appear more fruitful for future developments in this area of enquiry in order to move towards a global history of domestic workers and caregivers.

For a long time, scholars assumed that domestic service (especially live-in) would decline or even disappear because of household modernization, social progress, and development of the welfare state. Although actually declining in certain phases, paid domestic and care work never completely disappeared; moreover, in the past three decades in many countries it has experienced a "revival". I am interested in studying the forecasts of the disappearance of domestic service and paid domestic work, and in understanding why they have proven inadequate or wrong, for both scientific and political reasons. I believe that organizing work and services in order to reduce the numbers of domestic workers should still be a goal for policy makers.

\section{FORERUNNERS}

Historical research on domestic servants is not restricted to recent decades, as I will illustrate with three examples. In I 8 I4, Abbé Grégoire, the former "constitutional" priest who took part in the French Revolution and fought against slavery, published a well-researched book entitled De la domesticité chez les peuples anciens et modernes which described the transformation of domestic service over time and tried to show clear differences in the working conditions and legal position of servants in different countries, regions, and cities. The aim of the book was practical rather than theoretical: it sought to contribute to the formation of "good domestics". ${ }^{2}$ Later in the nineteenth century, other French scholars also focused on domestic service; often motivated by curiosity, they compared conditions for servants before and after the Revolution. ${ }^{3}$ Some idealized a past of presumed harmony

2. Henri Jean-Baptiste Grégoire, De la domesticité chez les peuples anciens et modernes (Paris, I 8 I4). See Albert Soboul, Une conscience religieuse en temps de révolution: L'abbé Grégoire, in Henri Grégoire, Oewvres, I4 vols (Nendeln, Lichtenstein [etc.], I977), I, pp. ix-xi.

3. François Pérennes, De la domesticité avant et depuis 1789 , ou discours sur cette question: comparer les rapports actuels des domestiques et des maitres avec ce qu'ils étaient avant la Révolution, et indiquer les moyens d'améliorer ces rapports (Paris, 1844). Among books published before World War I, see Edmond Robert, Les domestiques: Étude de moeurs et d'histoire (Paris, I875); Henri Renault Du Motey, L'esclavage à Rome. Le servage an Moyen Age. La domesticité dans le temps modernes (Douai, I88I); Robert Guerlin, Les serviteurs d'autrefois (Amiens, I893); Alfred Franklin (ed.), La vie de Paris sous Louis XIV: Tenue de maison et domesticité (reprint of Audiger, La Maison réglée ou L'Art de diriger la maison d'un grand seigneur et autres [...] [1692], and of Claude Fleury, Les Devoirs des maitres et des domestiques [1688]), in idem, La vie privée d'autrefois: Arts et métiers, modes, moeurs, usages des Parisiens, 
between masters and servants (which was generally not the case); others had a more rigorous approach, such as, for instance, Albert Babeau. ${ }^{4}$

The second example is Italian medieval and Renaissance cities, where domestic staff might include enslaved women (mainly from eastern Europe and central Asia). In the I860s, serious studies on the subject, based on archival research, began to be published.' That such slavery existed so late elicited surprise; the common opinion was that slavery had disappeared before the Renaissance. ${ }^{6}$ This hotly debated finding prompted a flow of studies which continues to the present day, ${ }^{7}$ and has gradually shifted later the "end" of (legal) slavery in Italy to the nineteenth century. ${ }^{8}$ It has also contributed to the history of slavery in the Mediterranean, a field of burgeoning research. ${ }^{9}$

du XIIe au XVIIIe siècle, d'après des documents originaux ou inédits (Paris, I 898), vol. XXIII; Georges d'Avenel, "Le train de maison depuis sept siècles: Les domestiques", Revue des Deux Mondes, 8 (1912), pp. 632-655.

4. Albert Babeau, "Les domestiques d'autrefois", Le Correspondant, I 39 (I885), pp. 23 I-256; idem, Les artisans et les domestiques d'autrefois (Paris, I886).

5. Vincenzo Lazari, "Del traffico e delle condizioni degli schiavi in Venezia nei tempi di mezzo", in Miscellanea di storia italiana edita per cura della Regia Deputazione di Storia Patria (Turin, I 862), I, pp. 463-501; Salvatore Bongi, "Le schiave orientali in Italia”, Nuova Antologia, 2 (I 866), pp. $215-246$.

6. Nino Tamassia, La famiglia italiana nei secoli decimoquinto e decimosesto (Milan [etc.], n.d. [c.I9I I]), pp. 352-353; Agostino Zanelli, Le schiave orientali a Firenze nei secoli XIV e XV (Florence, I885, and Sala Bolognese, I976), pp. 8-9.

7. On later developments see, for instance, Iris Origo, "The Domestic Enemy: The Eastern Slaves in Tuscany in the Fourteenth and Fifteenth Centuries", Speculum, 30 (1955), pp. 32 I-366; Charles Verlinden, L'esclavage dans l'Europe médiévale, 2 vols (Bruges, 1955, and Ghent, 1977); Franco Angiolini, "Schiave”, in Angela Groppi (ed.), Donne e lavoro (Rome [etc.], 1996), pp. 92-I I 5; Sally McKee, "Domestic Slavery in Renaissance Italy", Slavery and Abolition, 29 (2008), pp. 305-326. 8. Raffaella Sarti, "Tramonto di schiavitù: Sulle tracce degli ultimi schiavi presenti in Italia (sec. XIX)”, in Felice Gambin (ed.), Alle radici dell'Europa: Mori, gindei e zingari nei paesi del Mediterraneo occidentale, secoli XVIII e XIX (Florence, 2009), II, pp. 28 I-297.

9. For instance Salvatore Bono, "La schiavitù nel Mediterraneo moderno: storia di una storia", Cabiers de la Mediterranée, 65 (2002), available at: http://cdlm.revues.org/28; last accessed 19.1 2.201 3; Aurelia Martín Casares, La esclavitud en la Granada del Siglo XVI: Género, raza y religión (Granada, 2000); Giovanna Fiume, Schiavitù mediterranee: Corsari, rinnegati e santi di età moderna (Milan, 2009); Roger Botte and Alessandro Stella (eds), Couleurs de l'esclavage sur les deux rives de la Méditerranée (Moyen Âge-XXè siècle) (Paris, 2012). For a long time, and with only a few exceptions, this field of studies was restricted to Italian and French scholars. American scholars started to focus on this issue more recently, particularly when conflicts with the Muslim world became sharper (especially after I I September 200I). As a consequence, the "Barbary wars", which the US fought against north African Muslims at the beginning of the nineteenth century (because of the enslavement of Americans by Muslims), as well as the more general history of Mediterranean slavery, have entered into the public discourse and the scholarly agenda more often than in the past. See, for instance, Andrea Pelizza, "'Maybe We Are Still Fighting the Same War': Gli Stati Uniti tra i corsari del XVIII secolo e i terroristi del XXI", Società E Storia, I26 (2009), pp. 587-6I4. Mediterranean slavery was completely different from its Atlantic counterpart, because, especially from the sixteenth century onwards, 
The third example is the well-documented I 897 book Domestic Service, by Lucy Maynard Salmon (1853-1927), an American historian, professor at Vassar College, democrat, and suffragist. ${ }^{10}$ The volume remained the most important book on the subject until the I970s-I980s, when studies by Katzman, Sutherland, Dudden, Salinger, and Palmer were published. ${ }^{\text {II }}$ Salmon interpreted domestic service as an aristocratic residue which perpetuated personal subordination and dependence and aimed to contribute to solving the "the great American question" (p. I), i.e. the reciprocal dissatisfaction of servants and masters. Her book not only looked towards the past; it also described the present and provided suggestions for the future: the stigmatization of servants should be overcome; as many domestic chores as possible should be moved outside the domestic sphere; the work should be performed only on a strictly contractual basis; masters and servants should stop living under the same roof; both domestic and extra-domestic work should be more equally divided among men and women.

\section{THE SERVANT PROBLEM, THE TRANSFORMATION OF SERVICE, AND THE DEVELOPMENT OF NEW RESEARCH}

"Employers on both sides of the Atlantic meet with the same serious difficulties in their efforts to secure competent household employees", Salmon wrote. ${ }^{\mathrm{I2}}$ As the nineteenth century ended and the twentieth began, people all over Europe shared the idea that there was a crisis in domestic service: the "servant problem", "servant shortage", or "great question", "crise de la domesticite" in French, "crisi delle domestiche" in Italian, "Dienstbotenfrage" in German, and so forth. ${ }^{13}$ On the continent, public opinion partly envisaged an

both Muslims and Christians could be enslaved if captured, especially by members of the other religion: slaves were mainly employed as rowers or domestic servants; they could be ransomed or exchanged and thus often returned home.

I0. Lucy Maynard Salmon, Domestic Service (New York [etc.], I90 I [1897]). On the author see Louise Fargo Brown, Apostle of Democracy: The Life of Lucy Maynard Salmon (New York [etc.], I943), and the website: http://vcencyclopedia.vassar.edu/faculty/prominent-faculty/lucymaynard-salmon.html; last accessed 29.1.2014.

I I. David Manners Katzman, Seven Days a Week: Women and Domestic Service in Industrializing America (New York, 1978); Daniel E. Sutherland, Americans and their Servants: Domestic Service in the United States from I 800 to 1920 (Baton Rouge, LA [etc.], 1981); Faye E. Dudden, Serving Women: Household Service in Nineteenth-Century America (Middletown, CT, I983); idem, "Experts and Servants: The National Council on Household Employment and the Decline of Domestic Service in the Twentieth Century", Journal of Social History, 20 (1986), pp. 269-289; Sharon Vineberg Salinger, "To Serve Well and Faithfully": Labor and Indentured Servants in Pennsylvania, I682-I800 (Cambridge, MA [etc.], I987); Phyllis Palmer, Domesticity and Dirt: Housewives and Domestic Servants in the United States, 1920-1945 (Philadelphia, PA, 1989). I 2. Salmon, Domestic Service, p. 278; the chapter on Europe was added in the 2nd edition. I3. See for instance Prosper-Georges-Marcelin Bouniceau-Gesmon, Domestiques et maitres: $\grave{A}$ propos de quelques crimes récents (Paris, I885); Marcel Cusenier, Les domestiques en France (Paris, I9I 2); Oskar Stillich, Die Lage der weiblichen Dienstboten in Berlin (Berlin [etc.], 1902); 
(idealized) good old servant, loyal and faithful to his or her masters. Through propaganda that exalted the value of domestic service and urged masters to adopt a paternalistic attitude towards servants, they hoped to revive this ideal. Since the problem was to find domestics who were morally impeccable and good at their jobs, the drive for obedient and respectful servants often intermingled with efforts to "professionalize" domestic personnel. ${ }^{\mathrm{I}}$

Many others, particularly those who believed that the shortage of servants was a consequence of backward working conditions within

Else Kesten-Conrad, “Zur Dienstbotenfrage: Erhebungen der Arbeiterinnenschutzkommission des Bundes Deutscher Frauenvereine", Archiv für Sozialwissenschaft und Sozialpolitik, 3 I (1910), pp. 520-553; Riccardo Bachi, La serva nella evoluzione sociale (Turin, I900); Alessandro Levi, "Il 'completo': A proposito della crisi dei domestici", Critica sociale, 46 (1908), n. I, pp. I0-I 3; n. 2, pp. 26-28; n. 3, pp. 42-45; Alessandro Schiavi, "Per le domestiche", Critica sociale, 46 (1908), n. 4, pp. 56-58; Clementina Giusti Pesci, Proposta per la classe delle domestiche presentata alla assemblea delle Donne Italiane il 3 Marzo I9I3 (Bologna, I9I3); Nina Rignano Sullam, Le addette ai lavori domestici (Milan, I9I4); Salmon, Domestic service; Isaac Max Rubinow, "The Problem of Domestic Service", Journal of Political Economy, I4 (1906), pp. 502-519. As for research on this period, see on Italy: Flores Reggiani, "Un problema tecnico e un problema morale: La crisi delle domestiche a Milano (I890-I914)", in Ada Gigli Marchetti and Nanda Torcellan (eds), Donna lombarda I860-1945 (Milan, I992), pp. I49-179; Raffaella Sarti, "Da serva a operaia? Trasformazioni di lungo periodo del servizio domestico in Europa”, Polis. Ricerche e studi su società e politica in Italia, I9 (2005), pp. 9 I-I 20; on France: Pierre Guiral and Guy Thuillier, La vie quotidienne des domestiques en France au XIXe siècle (Paris, 1978); Anne Martin-Fugier, La place des bonnes: La domesticité féminine à Paris en 1900 (Paris, 1979), pp. 33-38; on Belgium: Valérie Piette, Domestiques et servantes: Des vies sous condition. Essai sur le travail domestique en Belgique au Ige siècle (Brussels, 2000), pp. 327-4I I; on Germany: Uta Ottmüller, "Dienstbotenfrage und Dienstbotenbewegung zu Beginn dieses Jahrhunderts", in Dokumentationsgruppe der Sommeruniversität V (ed.), Frauen als bezablte und unbezablte Arbeitskräfte: Beiträge zur Berliner Sommeruniversität für Franen. Oktober 1977 (Berlin, 1978), pp. 438-443; Heidi Müller, Dienstbare Geister: Leben und Arbeitswelt städtischer Dienstboten (Berlin, I985); Gertraud Zull, Das Bild vom Dienstmädchen um die Jahrhundertwende: Eine Untersuchung der stereotypen Vorstellungen über den Charakter und die soziale Lage des städtischen weiblichen Hauspersonals (Munich, 1984); Dorothee Wierling, Mädchen für alles: Arbeitsalltag und Lebensgeschichte städtischer Dienstmädchen um die Jahrbundertwende (Berlin [etc.], I987); Toni Pierenkemper, "'Dienstbotenfrage' und Dienstmädchenarbeitsmarkt am Ende des I9. Jahrhunderts”, Archiv für Sozialgeschichte, 28 (1988), pp. 173-20I; on Austria: Marina Tichy, Alltag und Traum: Leben und Lektüre der Dienstmädchen im Wien der Jabrbundertwende (Vienna, 1984), pp. 16-23; on Britain: Pamela Horn, The Rise and Fall of the Victorian Servant (Dublin [etc.], 1975), pp. I5 I-165; Theresa M. McBride, The Domestic Revolution: The Modernization of Household Service in England and France I 820-I920 (London, I976), p. 28 and passim; on Norway: A. Ellen Schrumpf, "Domestic Servants and Housewives: Controversies in Kristiania at the End of the 19th Century", paper presented at the seminar Servant Adaptability to the Labour Market: Domestic Service in Europe in a Stage of Transition, Oslo, I3-16 June 2002, abstract available in Suzy Pasleau and Isabelle Schopp (eds), with Raffaella Sarti, Proceedings of the Servant Project, 5 vols (Liège, 2005), II, pp. I67-I68.

I4. Raffaella Sarti, "Conclusion: Domestic Service and European Identity", in Pasleau and Schopp, with Sarti, Proceedings of the Servant Project, V, pp. 195-284, in part. pp. 248-252. 
domestic service, ${ }^{\text {Is }}$ dreamed of a better future. For instance, the German socialist leader August Bebel, in his extremely successful book Die Fran und der Sozialismus (1879), suggested that private kitchens should be replaced by communal ones equipped with every kind of modern (electric) appliance to make work easier. Communal solutions should be adopted for washing and laundry, too. ${ }^{16}$ This radical revolution of the household would lead to the disappearance of both servant and mistress. ${ }^{17}$ Other authors had similar ideas. ${ }^{18}$

On the other side of the Atlantic, at the beginning of the twentieth century Christine Frederick, in a completely different but also extremely successful book, proposed a new, rationalized system of housekeeping based on the application of Taylorism to housework. Like many others, she too suggested that, to solve the servant problem, servants should no longer live with their employers. ${ }^{19}$

In summary, about a century ago the belief that traditional servants would disappear was quite widespread. It was shared by people who simply noticed, and often regretted, that hiring a (good) servant was becoming increasingly difficult; by people who thought that servants would be replaced by a new kind of domestic worker, more independent and similar to factory workers; and by people who pictured a completely new society without any kind of servants. The persistence of this idea in the succeeding years contributed to making the study of domestic service less interesting. The history of the lower classes would for several decades indeed mainly focus on the formation of the "modern" working class and the development of class consciousness. Servants remained in the shadows: they were employed in a sector that from the late eighteenth century had

I 5. According to Salmon, Domestic Service, pp. 278-279, both in Europe and America women "prefer work in factories where the hours of work are definitely prescribed and evenings and Sundays are free; [...] in shops where their individual life is less under control [...]; in hotels [...] since these give opportunity for specialized work, a life of variety and excitement, and larger wages in the form of fees; [...] prefer short engagements with large fees at summer resorts to permanent engagements with moderate wages in families; because the growing spirit of democracy rebels against the inferior social position accorded household employees, even to those whose work is rightly classed as skilled labor". On the different ways of interpreting the crisis, its reasons, and its possible solutions, see among others Zull, Das Bild vom Dienstmädchen, pp. 52-198; Wierling, Mädchen für alles, pp. I 83-222, 283-296; Reggiani, "Un problema tecnico e un problema morale"; Sarti, "Da serva a operaia?", pp. 92-99.

16. August Bebel, Die Fran und der Sozialismus (Bonn, 1994, which follows the 5oth edn, printed in I910 [1879]), ch. 27, section 3 (Kommunistische Küche), available at: http://gutenberg.spiegel.de/ bebel/frausoz/frau274I.htm; last accessed I9.I2.20I3.

17. Ibid., ch. 27, section 4 (“Umwandlung des häuslichen Lebens").

18. See Müller, Dienstbare Geister, pp. $172-178$, for debates at the turn of the nineteenth to the twentieth century about the future development of households without servants.

19. Christine Frederick, The New Housekeeping: Efficiency Studies in Home Management (New York, I914), p. 178. 
been increasingly considered unproductive; they were barely present on the political scene; and, to an increasing degree, they were women because of the growing feminization of domestic personnel, ${ }^{20}$ a role that thus did not particularly appeal "at a time when history was still largely 'his-story", ${ }^{21}$ as later feminist historians would denounce.

\section{TRANSFORMATION IN THE TWENTIETH CENTURY}

Census data, despite its many limits and problems, indeed confirm that the percentage of domestic servants in the economically active population declined in several countries after having peaked in I880-I88I. ${ }^{22}$ Contemporaries thus had good reason to think that there was a crisis at the turn of the century.

Yet between the I920s and the I930s this trend stopped or reversed in many European countries, in the US and even in post-revolutionary Russia. This reversal resulted from the economic crisis and, in some countries, from specific policies aimed at placing unemployed women in domestic service and/or at expanding the domestic service sector. ${ }^{23}$ Nevertheless, the idea of a shortage of (good) domestics did not completely recede. Besides, neither advances in household technology nor people's diminishing need for personal help seemed to eliminate the need for servants. Some people, therefore, started to look for new solutions to the servant problem. One of them was Alva Myrdal in Sweden, who suggested that some domestic work should be changed into wage labour with the state as employer. In other words, she suggested resolving the servant problem by cultivating public welfare services. ${ }^{24}$

After World War II, new public welfare services multiplied in several countries. They contributed to a new, significant fall in the

20. See e.g. Cissie C. Fairchilds, Domestic Enemies: Servants and Their Masters in Old Regime France (Baltimore, MD [etc.], 1984), p. xi. See also McBride, The Domestic Revolution, p. 9; Guiral and Thuillier, La vie quotidienne des domestiques, pp. I6-I7; Sarah C. Maza, Servants and Masters in Eighteenth-Century France: The Uses of Loyalty (Princeton, NJ, 1983), p. 4; Claude Petitfrère, L'oeil du maître: Maîtres et serviteurs, de l'époque classique au romantisme (Brussels, 1986), p. 7.

2 I. Fairchilds, Domestic Enemies, p. xi. See also, for instance, McBride, The Domestic Revolution, p. 9; Guiral and Thuillier, La vie quotidienne des domestiques, pp. 14-17, 250; Maza, Servants and Masters, p. 4; Karin Walser, Dienstmädchen: Franenarbeit und Weiblichkeitsbilder um 1900 (Frankfurt a. Main, I985 and 1986), p. 7; Wierling, Mädchen für alles, pp. I 2-I 3.

22. On the 1880 s in France and Britain see McBride, The Domestic Revolution, p. 34; Olivier Marchand and Claude Thelot, Deux siècles de travail en France: Population active et structure sociale, durée e productivité du travail (Paris, 1991), p. I02.

23. Raffaella Sarti, "Domestic Service: Past and Present in Southern and Northern Europe", Gender and History, I 8 (2006), pp. 222-245.

24. Ellinor Platzer, "From Private Solutions to Public Responsibility and Back Again: The New Domestic Services in Sweden", Gender and History, I 8 (2006), pp. 2 I I-22 I. 


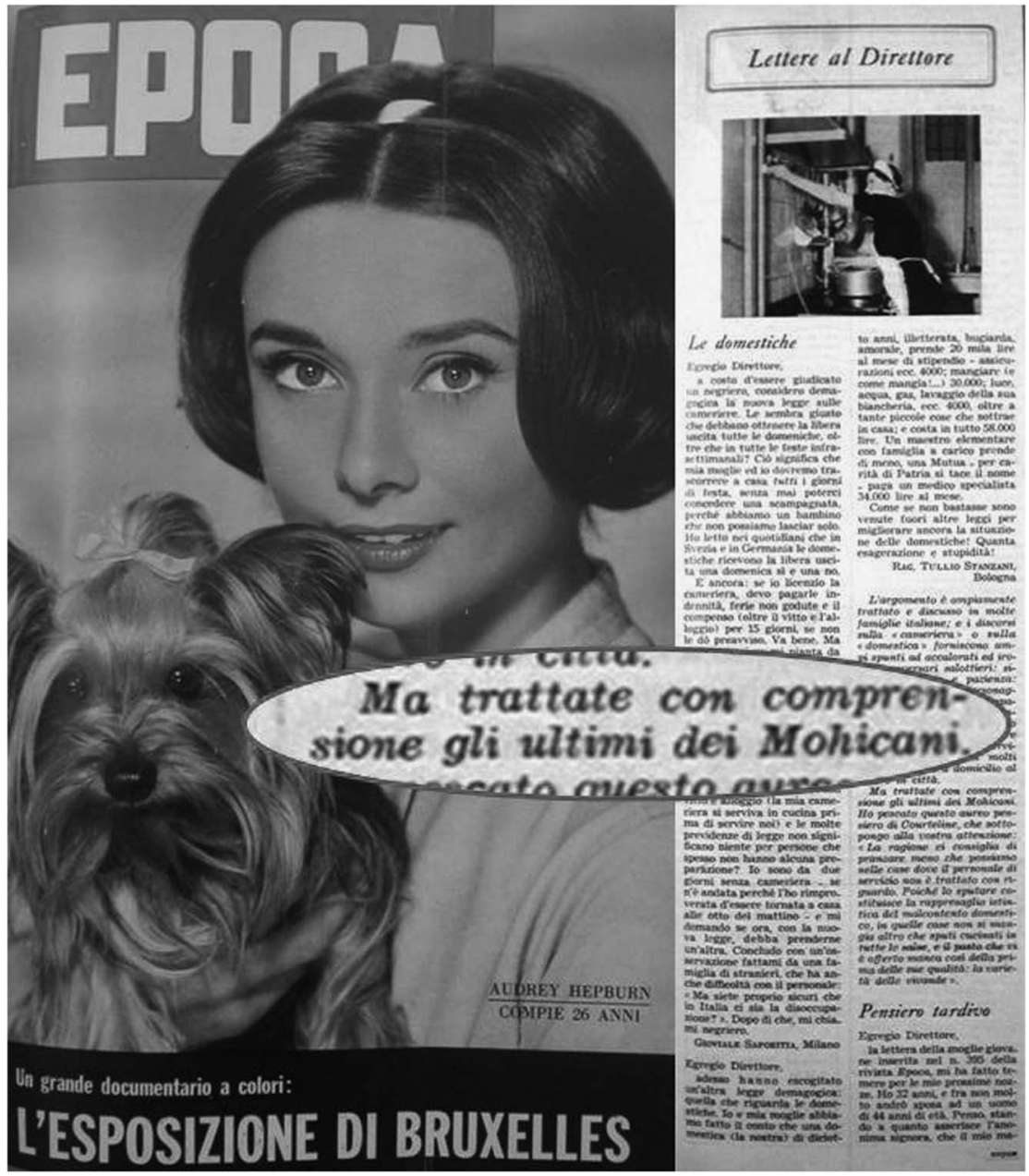

Figure I. In 1958, a law was approved in Italy that regulated domestic work (Law 339 of 2 April 1958). The law reduced (but did not eliminate) discrimination against domestic workers; they now enjoyed some rights, though less than many other workers. Nevertheless, many employers protested. Some of them wrote angry letters to newspapers and magazines complaining about the new rights granted to maids. This was true of the popular magazine Epoca whose editor, the well-known journalist Enzo Biagi, while replying to disgruntled readers, invited them to be patient and to treat their domestics compassionately: in his view, they were "gli ultimi dei Mohicani" ("the last of the Mohicans"). Epoca, 398, I8 May 1958; photograph by Raffaella Sarti.

number of domestic workers in Europe and in the US. ${ }^{25}$ This strengthened the idea that domestic service would evaporate thanks

25. Sarti, "Domestic Service and European Identity", pp. 277-278; idem, "Domestic Service: Past and Present”, p. 223, Table I. 
to "progress", ${ }^{26}$ and reduced, for social scientists, the interest in studying it. Domestic servants became an object of investigation mainly for historians, ${ }^{27}$ who, however, began to study them with new curiosity thanks to the spread of social history, the history of the family, historical demography, and (particularly from the 1970s) women's and gender history.

\section{FIFTY YEARS OF RESEARCH ON DOMESTIC SERVICE}

In 1954, Joseph Jean Hecht published an article on "Continental and Colonial Servants in Eighteenth Century England", and, two years later, a book on the The Domestic Servant Class in Eighteenth-Century England, which for several years was to remain the most comprehensive study on English middle- and upper-class domestic staff. The title and content of Hecht's article might suggest that historical studies on domestic service in Britain were going to take colonialism into account. Yet this was not the case: even Hecht's book did not deal with colonialism; nor did other studies focus on the issue - this aspect was taken up only very recently. ${ }^{28}$

A few years later Philippe Ariès, in his very influential book L'enfant et la vie familiale sous l'ancien régime stressed the importance of domestic service for the transmission of knowledge and values from one generation to the next in medieval and early modern times. School played a limited role and apprenticeship was crucial. Apprentices lived with their masters, as did young aristocrats placed as pages in families more important than their own. This was one of the reasons why, in Ariès' view, the relationship

26. Nevertheless, Lucy Delap has recently shown that being a "modern" middle-class woman always implied, at least in Britain, having some domestic help; Lucy Delap, Knowing their Place: Domestic Service in Twentieth-Century Britain (Oxford, 201 I), pp. 98-139.

27. Social scientists who focused on domestic service include George Joseph Stigler, future Nobel prize winner in economic science (1982) and author of Domestic Servants in the United States, I900-1940 (New York, I946); James H.S. Bossard, who in his very influential book The Sociology of Child Development (New York, 1948) briefly analysed the role of domestic servants (pp. 265-267); and Gretel Keller, Hausgehilfin und Hausflucht, ein soziales Problem von gestern und beute (Dortmund, 1950). Some of them explicitly denounced its crisis; see e.g. Vilhelm Aubert, "The Housemaid: An Occupational Role in Crisis", Acta Sociologica, I (1956), pp. I 49-1 58 . In some countries, such as Spain, there was a certain interest in the legal evolution of domestic service. See, among others, María Dolores Galvarriato, "Notas para la historia del servicio doméstico", Revista del Trabajo, 8 (1946), pp. I43-I47; Alejandro M. Unsaín, "Evolución del servicio doméstico", Revista del Trabajo, Io (1948), pp. I6-20; Luis Joaquín, Pedregal, Evolución legal del servicio doméstico (estudio histórico-jurídico) (Seville, I95 I).

28. Joseph Jean Hecht, "Continental and Colonial Servants in Eighteenth Century England", Smith College Studies in History, 40 (1954), pp. I-6I; idem, The Domestic Servant Class in Eighteenth-Century England (London, 1956), republished as The Domestic Servant in Eighteenth Century England (London [etc.], 1980). Among recent contributions on domestic service in Britain which deal with colonialism and imperialism see Pamela Horn, Life below Stairs in the Twentieth Century (Stroud, 2001). 
between parents and children was rather cold. ${ }^{29}$ On one hand, Aries' interpretation was criticized, but on the other, it inspired ample research on the history of the family, childhood, emotions, transmission of values and culture between generations, and also domestic service. ${ }^{30}$

Several studies have focused, indeed, on the role of domestic servants (both children and adults) in appropriating the values and customs of the upper classes and spreading them among the lower classes, such as, for instance, the book by Daniel Roche on the peuple de Paris in the eighteenth century. ${ }^{31}$ In investigating emotions within the family, scholars have also, in later years, examined the emotional and cultural influence of servants, wet-nurses, nannies, and governesses on their masters' children. ${ }^{32}$

29. Philippe Ariès, L'enfant et la vie familiale sous l'ancien régime (Paris, I960); idem, "Le service domestique: Permanence et variations", XVIIe Siècle, 32 (1980), pp. 4I 5-420.

30. Among articles and books on childhood and youth which also have focused on servants, see, for instance, John Randall Gillis, Youth and History: Continuity and Change in European Age Relations, I770 to Present (New York, 1974); Michael Mitterauer, Sozialgeschichte der Jugend (Frankfurt a. Main, I986); Ilana Krausman Ben-Amos, "Service and the Coming of Age of Young Men in Seventeenth-Century England", Continuity and Change, 3 (1988), pp. 4I-64; idem, Adolescence and Youth in Early Modern England (New Haven, CT [etc.], 1994); Jeremy Goldberg, "Orphans and Servants: The Socialization of Young People Living Away from Home in the English Later Middle Ages”, in Mireille Corbier (ed.), Adoption et Fosterage (Paris, 1999), pp. 23 I-246; Carlo Pancera, "L'infanzia laboriosa: Il rapporto maestro-apprendista", in Egle Becchi (ed.), Il bambino sociale: Privatizzazione e deprivatizzazione dell'infanzia (Milan, 1979), pp. 77-I 13; Giacomo Casarino, "I giovani e l'apprendistato: Iniziazione e addestramento", Quaderni del Centro di studio sulla storia della tecnica del Consiglio Nazionale delle Ricerche, special issue "Maestri e garzoni nella società genovese fra XV e XVI secolo", 4 (1982), pp. 5-178; Luciano Marcello, "Andare a bottega: Adolescenza e apprendistato nelle arti (sec. XVI-XVII)", in Ottavia Niccoli (ed.), Infanzie: Funzioni di un gruppo liminale dal mondo classico all'Età moderna (Florence, 1993), pp. 23 I-25 I; Anna Bellavitis, "Apprentissages masculins, apprentissages féminins à Venise au XVIe siècle”, Histoire Urbaine, is (2006), pp. 49-73; Patrizia Delpiano and Raffaella Sarti (eds), "Servants, Domestic Workers and Children: The Role of Domestic Personnel in the Upbringing and Education of the Master's and the Employer's Children from the Sixteenth to the Twenty-First Century", special issue of Paedagogica Historica, 4 (2007); Isabel dos Guimarães Sá, "Up and Out: Children in Portugal and the Empire (I 500-1800)", in Ondina E. González and Bianca Premo (eds), Raising an Empire: Children in Early Modern Iberia and Colonial Latin America (Albuquerque, NM, 2007).

3r. Daniel Roche, "Les domestiques comme intermédiaires culturels", in Les intermédiaires culturels: Actes du Colloque du Centre Méridional d'Histoire Sociale, des Mentalités et des Cultures (Aix-en-Provence [etc.], 1978), pp. 189-202; idem, Le peuple de Paris (Paris, 1981). Already Hecht, The Domestic Servant, pp. 200-228, had defined the "servant class as cultural nexus" connecting rural and urban cultures.

32. For instance Daniela Perco (ed.), Balie da latte: Una forma peculiare di emigrazione temporanea (Feltre, I984); Fairchilds, Domestic Enemies; Irene Hardach-Pinke, Die Gouvernante: Geschichte eines Framenberufs (Frankfurt a. Main [etc.], I993); Ann Laura Stoler, "A Sentimental Education: Native Servants and the Cultivation of European Children in the Netherlands Indies", in Laurie Jo Sears (ed.), Fantasizing the Feminine in Indonesia (Durham, NC, 1997), pp. 7I-9I; idem, Carnal Knowledge and Imperial Power: Race and the Intimate in Colonial Rule (Berkeley, CA [etc.], 2002); Barbara Petzen, "Matmazels nell'harem: Le governanti europee 
Some years after Ariès' study, Peter Laslett published a book on preindustrial England entitled The World We Have Lost, in which he paid great attention to servants. ${ }^{33} \mathrm{~A}$ few years later, in 1969 , analysing servants, he concluded that "the substantial proportion of persons who turn out to be living in the households of others, other than those into which they were born, looks to us like something of a sociological discovery". ${ }^{34}$

In 1965 , another very influential essay was published by John Hajnal, who wrote that western Europe was characterized by a peculiar marriage pattern with a high proportion of single people and marriages at a late age. ${ }^{35}$ These two features reduced birth rates, contributing to a slowing in population growth. In Hajnal's view, this solution to population pressure was specific to western Europe. According to him, western Europeans married late because they had to acquire the ability and means to support a family before marrying. They often reached this goal by working as servants. Life-time single people were often servants, too. Service was thus at the very core of his theory. In the following years Hajnal, Laslett, ${ }^{36}$ and the scholars of the Cambridge Group for the History of Population and Social Structure further developed this model, going on to introduce the concept of life-cycle servants. ${ }^{37}$

The homeostatic mechanism initially suggested by Hajnal has been shown to be rather effective in north-western and central Europe, but not in other parts of the continent, either in the east or in the south (in particular in the Mediterranean region). Nor was life-cycle service common everywhere in western Europe. ${ }^{38}$ However, this hypothesis

nell'Impero ottomano", Genesis. Rivista della Società Italiana delle Storiche, I (2002), pp. 6I-84; Sarah Pech, "L'influence des nourrices sur la formation physique et morale des enfants qu'elles allaitent selon les médecins et moralistes espagnols des XVIe et XVIIe siècles”, Paedagogica Historica, 43 (2007), pp. 493-507; Véronique Pache Huber, "Delegation of Childcare as a Corner Stone of Children's Interethnic Relations”, in Véronique Pache Huber and Spyros Spyrou (eds), "Children Interethnic Relations in Everyday Life: Beyond Institutional Contexts", special issue of Childhood: A Journal of Global Child Research, I9 (2012), pp. 389-396.

33. Peter Laslett, The World We Have Lost (London, 1965).

34. Idem, "Size and Structure of the Household in England over Three Centuries", Population Studies, 23 (1969), pp. 199-223, 219.

35. John Hajnal, "European Marriage Patterns in Perspective", in David Victor Glass and David Edward Charles Eversley (eds), Population in History (London, 1965), pp. I0I-135. 36. John Hajnal, "Two Kinds of Pre-Industrial Household Formation Systems", in Richard Wall, Jean Robin, and Peter Laslett (eds), Family Forms in Historic Europe (Cambridge, I983), pp. 65-104, 96-97; Peter Laslett, "Family and Household as Work and Kin Group: Areas of Traditional Europe Compared", in ibid., pp. $513-563$.

37. Peter Laslett, "Characteristics of the Western Family Considered over Time", Journal of Family History, 2 (1977), pp. 89-1 I 5, I04, I I0; there is another version in idem, Family Life and Illicit Love in Earlier Generations (Cambridge, 1977), pp. I2-49.

38. The amount of literature on this issue is huge. For comparative data see, for instance, Michael Mitterauer, "Servants and Youth", Continuity and Change, (I990), pp. I I-38. 
contributed to a new approach. In the I960s-1970s, changes in the family were mainly understood to be a consequence of industrialization, whereas the model proposed by Laslett and Hajnal stressed the importance of particular types of marriage and family for making national economic development possible. Though criticized, their theories sparked dozens of papers, essays and books both on Europe and on other countries such as, for instance, Japan. In central Japan, according to Mary Louise Powell Nagata, villagers usually married and established an independent household after their service period ended, at the age of about twenty-three

On north-western Europe: Sheila McIsaac Cooper, "Service to Servitude? The Decline and Demise of Life-Cycle Service in England", The History of the Family, I० (2005), pp. 367-386; Beatrice Moring, "Servanthood, Marriage and Female Destinies in an Urban Environment", Pasleau and Schopp, with Sarti Proceedings of the Servant Project, IV, pp. 7I-97, also published with the title "Migration, Servanthood and Assimilation in a New Environment", in Antoinette FauveChamoux (ed.), Domestic Service and the Formation of European Identity: Understanding the Globalization of Domestic Work, I6th-2 Ist Centuries (Bern, 2004), pp. 43-70; Sølvi Sogner, "Domestic Service in Norway: The Long View", in Antoinette Fauve-Chamoux and Ludmila Fialová (eds), Le phénomène de la domesticité en Europe, XVIe-XXe siècles (Prague, 1997), pp. 95-105; Christer Lundh, "Life-Cycle Servants in Nineteenth Century Sweden: Norms and Practices", in Fauve-Chamoux, Domestic Service, pp. 7 I-85, and in Pasleau, Schopp, and Sarti, Proceedings of the Servant Project, III, pp. 69-82; Richard Paping, "Oferta y demanda de criados rurales en Holanda, 1760-1920", in Carmen Sarasúa (ed.), "Criados y mozos en la organización histórica del trabajo agrario", special issue of Historia Agraria, 35 (2005), pp. I I 5-I 42; Hilde Bras, Aart C. Liefbroer, and Cees H. Elzinga, "Standardization of Pathways to Adulthood? An Analysis of Dutch Cohorts Born between I850 and 1900", Demography, 47 (2010), pp. I013-1034; Jeremy Hayhoe, "Rural Domestic Servants in Eighteenth-Century Burgundy: Demography, Economy, and Mobility", Journal of Social History, 46 (2012), pp. 549-571; Deborah Simonton, “'Birds of Passage' or 'Career' Women? Thoughts on the Life Cycle of the Eighteenth-Century European Servant”, Women's History Review, 20 (201 I), pp. 207-225; on central Europe: Josef Ehmer, Heiratsverhalten, Sozialstruktur, Ökonomischer Wandel: England und Mitteleuropa in der Formationsperiode des Kapitalismus (Göttingen, I99I); Jürgen Schlumbohm, "Gesindedienst als Lebensphase und als Klassenphenomen: Mägde und Knechte in einem ländlichen Kirchspiel Nordwestdeutschlands. 1650-1860", in FauveChamoux and Fialová, Le phénomène de la domesticité, pp. 23-39; Mikołai Szołtysek, "Life-Cycle Service and Family Systems in the Rural Countryside: A Lesson from Historical East-Central Europe”, Annales de démographie historique (2009), pp. 53-94; Tamás Faragó, "Different Household Formation Systems in Hungary at the End of the Eighteenth Century: Variations on John Hajnal's Thesis", Historical Social Research/Historische Sozialforschung, 23 (1998), pp. 83-I I I the discussion on eastern Europe and Russia mainly deals with the status of serfs and servants: see, for instance, Alessandro Stanziani, "Serfs, Slaves, or Wage Earners? The Legal Status of Labour in Russia from a Comparative Perspective, from the Sixteenth to the Nineteenth Century", Journal of Global History, 3 (2008), pp. I83-202; information on lifecycle/lifetime serfs and servants can be found in Tracy Dennison, The Institutional Framework of Russian Serfdom (Cambridge, 20I I). On southern Europe see n. 40. For an overview see Raffaella Sarti, "Criados, servi, domestiques, Gesinde, Servants: For a Comparative History of Domestic Service in Europe (16th-19th Centuries)", Obradoiro de Historia Moderna, 16 (2007), pp. 9-39, available at: http://dspace.usc.es/bitstream/I0347/3909/I/pg_009-040_obradoiro I6.pdf; last accessed 20.12.20I3. 
for women and twenty-eight for men. In other words, service in central Japan showed some similarities with European life-cycle service. The role of domestic service in striking a balance between population and resources does not seem to be unique to western Europe in pre-industrial times. ${ }^{39}$

Further developments in the demographic approach to the history of the family include the article by David Reher on family ties. ${ }^{\circ}$ According to Reher, family ties today are stronger and public welfare is less advanced in those European regions, such as the Mediterranean, where life-cycle service was uncommon in the past, i.e. where young people generally did not leave the parental home at an early age, long before marrying. Reher's hypothesis has been criticized but, at the same time, has triggered much research. Moreover, it prompts us to analyse the relationship between private and public welfare.

In 1969 Abel Chatelain stressed the importance of domestic service in understanding urbanization, ${ }^{4 \mathrm{I}}$ another issue that would attract much attention in subsequent years. Later, Antoinette Fauve-Chamoux would even suggest that the particular sex ratio of pre-industrial cities, where women were generally the majority of the population, arose from the arrival of rural girls who worked as maids. ${ }^{42}$

When Chateleain published his article, the role of domestic servants in migration was not obvious. As described by Karin Walser, the emphasis on factory work as a specific feature of female modernity had led to a

39. Mary Louise Powell Nagata, "One of the Family: Domestic Service in Early Modern Japan", The History of the Family, 10 (2005), pp. 355-365.

40. David Sven Reher, "Family Ties in Western Europe: Persistent Contrasts", Population and Development Review, 24 (1998), pp. 203-235. On domestic service in southern Europe see, for instance, Angiolina Arru, "The Distinguishing Features of Domestic Service in Italy", Journal of Family History, is (1990), pp. 547-566; Giovanna Da Molin, "Family Forms and Domestic Service in Southern Italy from the Seventeenth to the Nineteenth Century", Journal of Family History, I ( (1990), pp. 503-527; Isidro Dubert, "Domestic Service and Social Modernization in Urban Galicia, I752-1920", Continuity and Change, I4 (1999), pp. 207-226; Serrana Mercedes Rial García, Mujer y actividad económica en la Galicia Moderna: La inserción de las mujeres en la producción económica rural y urbana (Santiago, 2003); the special issue of Historia agraria, 35 (2005) on rural servants; Violetta Hionidou, "Domestic Service on Three Greek Islands in the Later 19th and Early 2oth Centuries", The History of the Family, io (2005), pp. 473-489; Ofelia Rey Castelao, "Les femmes 'seules' du nord-ouest de l'Espagne: Trajectoires féminines dans un territoire d'émigration I700-1860", Annales de démographie historique, II 2 (2006), pp. I05-I33; Francisco García González, "Criados, Trabajo, Movilidad población, Castilla rural, Siglo XVIII”, in María José Pérez Álvarez, Laureano M. Rubio Pérez, Alfredo Martín García, and Francisco Fernández Izquierdo (eds), Campo y campesinos en la España Moderna: Culturas políticas en el mundo hispano (León, 2012), pp. I Iо I-I I 2.

4I. Abel Chatelain, "Migrations et domesticité féminine urbaine en France, XVIII siècle-XIX siècle", Revne d'bistoire économique et sociale, 47 (1969), pp. 506-528.

42. Antoinette Fauve-Chamoux, "Le surplus urbain des femmes en France préindustrielle et le rôle de la domesticité", Population, I (1998), pp. 359-377. 
focus on industrial work rather than on domestic service. The recognition that working in a traditional and "backward" sector such as domestic service had been the main avenue through which women of rural origin had become integrated into "modern" urban society and culture instigated an important change in the established interpretative framework. ${ }^{43}$ "Almost paradoxically it [domestic service] served as a means of the modernisation of rural labour and particularly of women", during industrialization and urbanization, Theresa McBride wrote in her landmark study The Domestic Revolution. The Modernisation of Housebold Service in England and France I 820-1920. ${ }^{44}$

Since the I970s, many works have focused on domestic service as a crucial channel for both migration and social mobility (upwards and downwards), particularly for women. ${ }^{45}$ Significantly, however, many of the earlier studies, even those that stressed the importance of domestic service within urbanization and modernization processes concluded that modernization would eventually entail the servants' marginalization. "Domestic service has retreated to a marginal role in the economies of most western societies" was the conclusion of McBride's book. ${ }^{46}$ In the same work she also maintained that in both England and France "domestic service reached its peak during the early decades of industrialisation". ${ }^{47}$ World War I was assumed by many scholars to have been the point at which the history of domestic service in "developed countries" came to an end.

McBride's conclusion supported the extremely influential thesis of the economist Ester Boserup. Boserup, in Women's Role in Economic Development, published in 1970, argued that in countries in the first phases of economic development domestic tasks are performed mainly by family members, whereas during the intermediate stages the personal services sector grows very large. Urbanization creates a demand for service personnel in bars and restaurants as well as in the homes of the newly rich entrepreneurial class. At the beginning, this expansion of domestic service involves both men and women, but over time the sector becomes more feminized. In fully industrialized countries, many services are no longer performed at home and the number of domestic workers is low. It is because of this trend, Boserup said, that female servants are particularly numerous in Latin America.

43. Walser, Dienstmädchen, pp. 7-8.

44. Theresa McBride, The Domestic Revolution: The Modernisation of Household Service in England and France I820-1920 (London, 1976), p. I17.

45. For instance, McBride, The Domestic Revolution, p. 9, considered domestic service as a "bridging occupation" as defined by L. Broom and J.H. Smith, "Bridging Occupations", British Journal of Sociology, I4 (1963), pp. 32 I-334; Wierling, Mädchen für alles, pp. 16, 67-83; Angiolina Arru, Il servo: Storia di una carriera nel Settecento (Bologna, I995), in part. pp. 2 I0-2 13.

46. McBride, The Domestic Revolution, p. I I6.

47. Ibid., p. 34 . 
Her suggestion, though criticized as too narrowly conceived, sparked research in regions such as Latin America and Africa. ${ }^{8}$

In the I970s, the idea that modernization and "progress" would precipitate the disappearance of domestic service was well established, and in I 973 the sociologist Lewis A. Coser spoke of the transformation of domestic service as "obsolescence of an occupational role": "that role is dying”, he maintained. ${ }^{49}$

The progress of feminism and historical research by feminist scholars inevitably inspired the study of domestic servants. A very important essay was published by Leonore Davidoff in 1974, "Mastered for Life: Servant and Wife in Victorian and Edwardian England", stressing the similarities between maids and mistresses, while also mentioning the limits to this parallelism. ${ }^{\circ}$ Thanks to feminism and the development of women's and gender history, an explosion of studies on domestic service took place. These studies focused on many different aspects, ${ }^{5 \mathrm{I}}$ traditional and new: ${ }^{52}$ the feminization of domestic service; ${ }^{53}$ the relationship of domestic service with people's life-cycle, marriage, and/or celibacy; ${ }^{4}$ its role in migration,

48. Ester Boserup, Women's Role in Economic Development (London, I970), pp. I03-104. For two examples of early articles dealing with domestic service in Latin America and/or Africa and also discussing Boserup's thesis, see Elizabeth Jelin, "Migration and Labor Force Participation of Latin American Women: The Domestic Servants in the Cities”, Signs, 3 (1977), pp. I29-141; Suellen Huntington, "Issues in Woman's Role in Economic Development: Critique and Alternatives", Journal of Marriage and Family, 37 (1975), pp. I00 I-IoI 2.

49. Lewis A. Coser, "Servants: The Obsolescence of an Occupational Role", Social Forces, I (I973), pp. 3I-40, 39 .

50. Leonore Davidoff, "Mastered for Life: Servant and Wife in Victorian and Edwardian England", The Journal of Social History, 7 (1974), pp. 406-428.

51. For instance, Leonore Davidoff and Ruth Hawthorn, $A$ Day in the Life of a Victorian Servant (London, 1976); Ottmüller, Dienstbotenfrage und Dienstbotenbewegung, pp. 438-443; idem, Die Dienstbotenfrage: Zur Sozialgeschichte der doppelten Ausnutzung von Dienstmädchen im deutschen Kaiserreich (Münster, 1978); Geneviève Fraisse, Femmes toutes mains: Essai sur le service domestiques. Recherches, discussions, documentation et interviews en collaboration avec Martine Guillin (Paris, 1979); Martin-Fugier, La place des bonnes; Angiolina Arru, "Lavorare in casa d'altri: Servi e serve domestici a Roma nell'800", in Annali della Fondazione Lelio e Lisli Basso-Issoco (Rome, 1983-1984), pp. 95-160.

52. Wierling, Mädchen für alles, pp. I4-15, for instance, contested the idea put forward by Rolf Engelsing that domestic work was a traditional and declining occupation: from women's point of view, it was an expanding one, and had new features in comparison with the past. For Engelsing's interpretation, see Rolf Engelsing, "Das häusliche Personal in der Epoche der Industrialisierung", Jabrbuch für Sozialwissenschaft, 20 (1969), pp. 84-I2 I, republished in a longer version in idem, Zur Sozialgeschichte deutscher Mitte- und Unterschichten (Göttingen, I978 [1973]), pp. 224-26I. See also Walser, Dienstmädchen, pp. 7-8.

53. Almost all the books and articles on domestic service in the eighteenth and nineteenth century analyse or at least mention the issue of feminization.

54. Leonore Davidoff, "Domestic Service and the Working-Class Life Cycle", Society of the Study of Labour History, 26 (1973), pp. IO-I 3; Louise A. Tilly and Joan W. Scott, Women, Work and Family (New York, 1978); Christiane Klapisch-Zuber, "Célibat et service féminins dans la 
urbanization, functioning of the labour market, and (upward or downward) social mobility; ${ }^{55}$ its connection with illegitimacy and prostitution; ${ }^{56}$ maid stereotypes, ${ }^{57}$ and their links to actual social practices ${ }^{58}$ (or their lack of such links $\left.{ }^{59}\right)$; domestic service as a shelter occupation, ${ }^{60}$ or as preparation for marriage; ${ }^{61}$ its role in leading to alienation and suicide; ${ }^{62}$ domestic chores performed by middle-class housewives as "ghosts", doing jobs that would formerly have been carried out by maids. ${ }^{63}$ Positive aspects of domestic service were also shown (mainly thanks to oral history and autobiography), such as the ability of the maid to improve her status by moving from the countryside to the city, to negotiate with mistresses, ${ }^{64}$ or

Florence du XVe siècle”, Annales de démographie historique, (198I), pp. 289-302; Angiolina Arru, "A che prezzo la carriera! Nubilato e servizio domestico a Roma nell'Ottocento", in Società Italiana di Demografia Storica, Popolazione, società, ambiente: Temi di demografia storica italiana (secc. XVII-XIX): Relazioni e comunicazioni presentate da Autori italiani al I Congrés Hispano Luso Italià de Demografia Histórica, Barcellona, 22-25 aprile 1987 (Bologna, 1990), pp. I03-I 23.

55. See e.g. McBride, The Domestic Revolution, pp. 9, 82-98; Carmen Sarasúa, Criados, nodrizas y amos: El servicio doméstico en la formación del mercado de trabajo madrileño, 1758-I868 (Madrid, I994).

56. McBride, The Domestic Revolution, pp. 99-1 ro; Penelope Wilcox, "Marriage, Mobility and Domestic Service”, Annales de demographie historique, (1981), pp. 195-206.

57. Fraisse, Femmes toutes mains; Martin-Fugier, La place des bonnes; Walser, Dienstmädchen. 58. Maria Casalini thought, for instance, that the association of the maid with the prostitute was not only a stereotype: "Le serve e i loro padroni", in Paola Nava (ed.) Operaie, serve, maestre, impiegate: Atti del convegno internazionale di studi: Il lavoro delle donne nell'Italia contemporanea: continuità e rotture (Carpi, 1990) (Turin, 1992), pp. 265-286, 276.

59. Karin Walser, "Prostitutionsverdacht und Geschlechterforschung: Das Beispiel der Dienstmädchen um 1900", Geschichte und Gesellschaft, I I (1985), pp. 99-1 I ; idem, Dienstmädchen, pp. 59-73; Margherita Pelaja, "Mestieri femminili e luoghi comuni: Le domestiche a Roma a metà Ottocento", Quaderni storici, 23 (1968), pp. 497-518. See also Reggiani, "Un problema tecnico e un problema morale", n. 50.

6o. Angiolina Arru, "Protezione e legittimazione: Come si usa il lavoro di serva nell'Ottocento", in Lucia Ferrante, Maura Palazzi, and Gianna Pomata (eds), Ragnatele di rapporti: Patronage e reti di relazione nella storia delle donne (Turin, 1988), pp. 38I-4I6; Daniela Lombardi and Flores Reggiani, "Da assistita a serva: Circuiti di reclutamento delle serve attraverso le istituzioni assistenziali (Firenze-Milano, XVII-XVIII sec.)", in Simonetta Cavaciocchi (ed.), La donna nell'economia, secc. XIII-XVIII, Istituto Internazionale di Storia Economica "F. Datini" (Florence, 1990), pp. 30I-319; Angela Groppi, I conservatori della virtù: Donne recluse nella Roma dei Papi (Rome [etc.], 1994), pp. I66-173; Shurlee Swain, "Maids and Mothers: Domestic Servants and Illegitimacy in I9th-Century Australia", The History of the Family, 10 (2005), pp. 46I-47I.

6r. See e.g. Davidoff, "Mastered for Life".

62. Regina Schulte, "Dienstmädchen im herrschaftlichen Haushalt: Zur Genese ihrer Sozialpsychologie", Zeitschrift für bayerische Landesgeschichte, 4I (1978), pp. 879-920; Guiral and Thuillier, La vie quotidienne des domestiques, pp. I30-1 32 .

63. Martin-Fugier, La place des bonnes, p. I i; Fraisse, Femmes toutes mains, p. I4; Walser, Dienstmädchen, pp. I I I-I 33 .

64. See e.g. Wierling, Mädchen für alles; Angiolina Arru, "Nel carattere scortese, nel comportamento impertinente e sfrontata'. Racconti di serve tedesche nell'Ottocento", in Angiolina 
to travel to distant places. ${ }^{65}$ Women's historians were generally well aware of the class divide between mistress and maid, ${ }^{66}$ yet they often also stressed the common female oppression in patriarchal households as well as the role of domestic service as "preparation" for marriage and motherhood. At the same time, they (especially European scholars) generally overlooked the issue of race, though they were sometimes conscious of its importance. ${ }^{67}$

Black and other non-white feminists reacted both to the emphasis on the common destiny of maids and mistresses and/or to the lack of attention to race. This was especially the case in the US, where race historically played a pivotal role in shaping the social destiny of people and strongly affected domestic service. Prepared by earlier studies, the article by E. Nakano Glenn, "From Servitude to Service Work: Historical Continuities in the Racial Division of Paid Reproductive Work", as well as the book by Mary Romero, Maid in the USA, both published in I992, have been particularly influential. ${ }^{68}$

The issue of race and ethnicity has become central in those studies that focus on domestic service in colonial or former colonial contexts, which have recently attracted increasing attention. ${ }^{69}$ Colonial domination and its legacy often actually entailed (and still entail) the employment of nonwhite servants by white (colonial) employers, ${ }^{70}$ sharpening the hierarchy

Arru and Maria Teresa Chialant (eds), Il racconto delle donne: Voci autobiografie figurazioni (Naples [etc.], I990), pp. I I-26.

65. For instance Hardach-Pinke, Die Gouvernante; M. Jeanne Peterson, The Victorian Governess: Status Incongruence in Family and Society, in Martha Vicinus (ed.), Suffer and Be Still: Women in the Victorian Age (Bloomington, IN [etc.], 1973), pp. 3-19; John Randall Gillis, "Servants, Sexual Relations, and the Risks of Illegitimacy in London, I80I-1900", Feminist Studies, 5 (1979), pp. I42-173.

66. See for instance Leonore Davidoff, "Class and Gender in Victorian England: The Diaries of Arthur Munby and Hannah Cullwick", Feminist Studies, 5 (1979), pp. 86-I4I.

67. Davidoff, "Mastered for Life", p. 425 , briefly mentions both Aban B. Mheta, The Domestic Servant Class (Bombay, 1960), and Michael G. Whisson and William Weil, Domestic Servants: A Microcosm of "the Race Problem" (Johannesburg, I97I).

68. Evelyn Nakano Glenn, "From Servitude to Service Work: Historical Continuities in the Racial Division of Paid Reproductive Work", Signs, I8 (1992), pp. I-43; see also idem, Issei, Nisei, War Bride: Three Generations of Japanese American Women in Domestic Service (Philadelphia, PA, 1986); Mary Romero, Maid in the USA (New York [etc.], 1992), roth Anniversary (revised) edn by Routledge published in 2002; see also Mary Romero, "Sisterhood and Domestic Service: Race, Class and Gender in the Mistress-Maid Relationship", Humanity E Society, I2 (1988), pp. 318-346.

69. An important conference was organized by Victoria Haskins at the University of Newcastle in 20I2, see "Colonization and Domestic Service: Historical and Contemporary Perspectives", Research Symposium, Newcastle, Crowne Plaza, 20I 2, at http://www.newcastle.edu.au/Resources/ Institutes/The \% 20 Australian\% 20 Institute $\%$ 20for $\%$ 20Social $\%$ 20Inclusion $\%$ 20and $\%$ 20Wellbeing/ Seminars/Colonization \% 20and \% 20Domestic\% 20Services_Program\% 20Final_web.pdf; last accessed 20.12.2013.

70. Victoria Haskins and Claire Lowrie (eds.), Colonization and Domestic Service: Historical and Contemporary Perspectives (London [etc.], 2014, forthcoming). 
typical of the master/servant relationship. ${ }^{7 \mathrm{I}}$ Colonizers, on the other hand, often viewed black slaves and native non-white indigenous servants with suspicion because they could have a very "negative" and contaminating influence on their masters, and especially, on their masters' children, as Ann Stoler has suggested in her very important work. Such an influence might indeed prevent the development of those children's cultural identity as "white" rulers; therefore the colonizers felt it should be avoided or at least limited. At the same time, however, native servants might appear fascinating, and emotional bonds could (and actually did) develop between them and their white masters (both children and adults). ${ }^{72}$ The issue of race and ethnicity was also very pressing because of the "importing" of white servants in several colonial contexts such as Canada and Australia in order to increase the white population and spread the colonizers' culture. ${ }^{73}$ At the same time, local native elites in colonized countries might be "interested" in employing white servants and governesses who could teach the rulers' manners and language to their children. ${ }^{74}$

Books and articles on Africa and Asia also illustrate different aspects of the complex intermingling of race, gender, and colonial rule. In many Asian and African contexts (unlike in Europe, the US, and Latin America), in the late nineteenth and twentieth centuries male domestics were numerous. Scholars who have focused on local male servants employed by white people in countries such as Zambia, India, and Malaysia, but also Australia ${ }^{75}$ have shown that they were subject to several forms of

7I. For instance, Alberto Rutté García, Simplemente explotadas: El mundo de las empleadas domésticas de Lima (Lima, I976 [1973]); Elsa M. Chaney and Mary Garcia Castro (eds), Muchachas No More: Household Workers in Latin America and the Caribbean (Philadelphia, PA, 1989).

72. Stoler, "A Sentimental Education"; idem, Carnal Knowledge and Imperial Power. Stoler focuses on emotions with an approach influenced by Michel Foucault; she does not mention Ariès. 73. See e.g. Marilyn Barber, Immigrant Domestic Servants in Canada (Ottawa, I991); Sedef Arat-Koc, "From 'Mothers of the Nation' to 'Migrant Domestic Workers"”, in Abigail B. Bakan and Daiva Stasiulis (eds), Not One of the Family: Foreign Domestic Workers in Canada (Toronto [etc.], 1997), pp. 53-79; Horn, Life Below Stairs, p. I6r; Christiane Harzig, "MacNamara's DP Domestics: Immigration Policy Makers Negotiate Class, Race, and Gender in the Aftermath of World War II", Social Politics, Io (2003), pp. 23-48; Paula Hamilton and Barry W. Higman, "Servants of Empire: The British Training of Domestics for Australia", Social History, 28 (2003), pp. 67-82.

74. For instance Petzen, “Matmazels nell'harem”, pp. 6I-84.

75. Karen Tranberg Hansen, "Household Work as a Man's Job: Sex and Gender in Domestic Service in Zambia", Anthropology Today, 2 (1986), pp. I 8-23; idem, Distant Companions: Servants and Employers in Zambia, 1900-1985 (Ithaca, NY [etc.], 1989). See also John Pape, "Still Serving Tea: Domestic Workers in Zimbabwe 1980-90", Journal of Southern African Studies, 19 (1993), pp. 387-404. Among more recent studies on the African context see Janet M. Bujra, Serving Class: Masculinity and the Feminisation of Domestic Service in Tanzania (Edinburgh, 2000); Maria Rita Bartolomei, "Migrant Male Domestic Workers in Comparative Perspective: Four Case Studies from Italy, India, Ivory Coast, and Congo", Men and Masculinities, I3 (2010), pp. 87-1 I0. 
de-virilization and inferiorization: male servants were culturally constructed and treated as "boys" even when they were adult. ${ }^{76}$

Karen Tranberg Hansen's book on domestic service in Zambia, published in 1989, was important not only because of its focus on male domestics, but also because of its contribution to the history of domestic service worldwide. Hansen noted that:

[...] the Zambian case is but a variation on the story of domestic labor which has no final, or single, conclusion, for it is still unfolding. Domestic service is not an archaic remnant of feudal practices persisting only in remote corners of the twentieth-century world. It represents a labor process that takes many different forms, and it employs growing, not decreasing numbers of workers in an advanced capitalist economy such as that of the United States today. ${ }^{77}$

While reviewing Hansen's volume and three others, Louise Tilly concluded in I99I that the books and essays under scrutiny effectively demolished "any notion that there is a simple inverse correlation between development and the proportion of women workers in domestic service, as Boserup suggested". "Rather than a simple linear process at the national level, development is a world-level process, in which economic inequality between and within national states is a critical factor." ${ }^{8}$

For a comprehensive history of masculinity and colonial rule in India see Mrinalini Sinha, Colonial Masculinity: The 'Manly Englishman' and the 'Effeminate Bengali' in the Late Nineteenth Century (Manchester, I995). On domestic workers see Raka Ray, "Masculinity, Femininity and Servitude: Domestic Workers in Calcutta in the Late Twentieth Century", Feminist Studies, 26 (2000), pp. 69i-7i 8; Swapna M. Banerjee, Men, Women, and Domestics: Articulating MiddleClass Identity in Colonial Bengal (New York, 2004); Seemin Qayum and Raka Ray, Cultures of Servitude: Modernity, Domesticity, and Class in India (Stanford, CA, 2009); idem, "Male Servants and the Failure of Patriarchy in Kolkata (Calcutta)", Men and Masculinities, I3 (2010), pp. III-I25; Bartolomei, "Migrant Male Domestic Workers". On other Asian contexts see Christine B.N. Chin, In Service and Servitude: Foreign Domestic Workers and the Malaysian 'Modernity' Project (New York, 1998), pp. 69-73. On Australia see Julia Martínez and Claire Lowrie, "Colonial Constructions of Masculinity: Transforming Aboriginal Australian Men into 'Houseboys', Gender and History, 21 (2009), pp. 305-323.

76. In the late ninteenth and early twentieth centuries, male domestic workers underwent a symbolic castration in many European countries, too. They were, for example, prevented from growing moustaches, which at the time were a sign of virility. Significantly, this prohibition provoked several protests, see Raffaella Sarti, "Fighting for Masculinity: Male Domestic Workers, Gender, and Migration in Italy from the Late Nineteenth Century to the Present", Men and Masculinities, I 3 (2010), pp. I6-43.

77. Hansen, Distant Companions, p. xii.

78. Louise A. Tilly, "Does Waged Domestic Labor Have a Future?”, International Labor and Working-Class History, 39 (199I), pp. 6I-7I, 70. The other three reviewed books are Chaney and Castro, Muchachas No More; Sandra Lauderdale Graham, House and Street: The Domestic World of Servants and Masters in Nineteenth-Century Rio de Janeiro (Cambridge, I988); Palmer, Domesticity and Dirt. 
In the I980s and the I990s, scholars increasingly questioned the idea that industrialization would bring about the retreat of domestic service. ${ }^{79}$ As early as 1984 Saskia Sassen had described the expanding flow, towards the US, of Third World women who would be employed in domestic service and in the informal sector, as well as the expansion of services and informal activities in the so-called global cities. ${ }^{80}$ In 1987 , Sassen and Alejandro Portes went on to question the theories according to which widespread informal economic sectors were a feature of Third World economies and were destined to wither away thanks to modern, industryled growth. They presented evidence that these activities were not waning in industrializing countries either, and that they were continuing or even experiencing a revival in the advanced economies (speaking of an "apparent revival"). ${ }^{81}$ A few years later, in 1994, two geographers, Niki Gregson and Michelle Lowe, in their book Servicing the Middle Classes, more overtly "announced" the "resurgence of paid domestic work" in Britain. ${ }^{82}$ Even though they were not the first to notice the phenomenon, ${ }^{83}$ their book

79. In 1978 David Chaplin still considered domestic service a "declining occupation", and maintained that its incidence "is a prime indicator of the level and quality of industrialization and modernization". Yet at the same time he noted that "as it 'casualizes' (with more part-time, seasonal, and short-term incumbents), it appears to disappear faster than is the case": fewer workers "can still serve more households than ever before"; they are less likely to be enumerated in the census; in the US "a sizeable proportion of the illegal immigrants from Latin America and the West Indies hide out as unreported domestic servants”; David Chaplin, "Domestic Service and Industrialization", Comparative Studies in Sociology, I (1978), pp. 97-I 27, 105-I06, I $23-124$.

80. Saskia Sassen-Koob, “The New Labor Demand in Global Cities”, in Michael Peter Smith (ed.), Cities in Transformation: Class, Capital, and the State (Thousand Oaks, CA, 1984), pp. 139-171; idem, "Notes on the Incorporation of Third World Women into Wage-Labor Through Immigration and Off-Shore Production", International Migration Review, I 8 (1984), pp. I I44-1 I67; in the same issue of the International Migration Review, Mirjana Morokvaśic, "Birds of Passage are also Women”, pp. 886-907, also stresses the high number of migrant domestic workers.

81. Alejandro Portes and Saskia Sassen-Koob, "Making it Underground: Comparative Material on the Informal Sector in Western Market Economies", American Journal of Sociology, 93 (1987), pp. 30-61. In 1991 Sassen published The Global City: New York, London, Tokyo (Princeton, NJ, I99I) that, among other things, stimulated scholars to analyse the composition of migration flows to different cities. Eleonore Kofman, in particular, stressed the diversity of migrant women; see Eleonore Kofman, "Beyond a Reductionist Analysis of Female Migrants in Global European Cities: The Unskilled, Deskilled and Professional”, in Marianne H. Marchand and Anne Sisson Runyan (eds), Gender and Global Restructuring: Sightings, Sites and Resistances, (London [etc.], 2000), pp. I29-I39.

82. Nicky Gregson and Michelle Lowe, Servicing the Middle Classes: Class, Gender and Waged Domestic Labour in Contemporary Britain (London [etc.], 1994), p. 4.

83. In Italy, for instance, as far back as 1977 the sociologist Olga Turrini in Le Casalinghe di riserva: Lavoratrici domestiche e famiglia borghese (Rome, I977), p. 34, had noted that domestic workers were not disappearing, as some thought, and she emphasized the growing presence of foreigners in the sector. In I991, John Clarke in New Times and Old Enemies: Essays on Cultural Studies and America (New York, I991), p. 174, highlighted the fact that in the US the 
was particularly influential. In the following years similar statements were made in other studies too. ${ }^{84}$

The year before, in 1993, the sociologist Bridget Anderson had published a book on those whom she called "Britain's secret slaves", i.e. overseas domestic workers. The publishers of the book were Anti-Slavery International, an organization founded in I 839 to work against slavery, and Kalayaan, a charity and company established in 1987 to provide advice, advocacy, and support services in the UK for migrant domestic workers. ${ }^{85}$ In 1994, the French journalist Dominique Torrès created the Comité contre l'esclavage moderne (Committee against modern slavery), and in 1996 she published a volume entitled Esclaves: 200 millions d'esclaves aujourd'bui denouncing the presence of "modern" slaves, often employed in domestic service. ${ }^{86}$

Many reports, books and articles focusing on contemporary slavery have started to appear. ${ }^{87}$ The uncovering of "modern slaves" and "modern slavery"

growing female presence in the labour market was often limited to marginal sectors, above all the service sector, where a "revival of domestic service" could be noted. At the time that Gregson and Lowe's book (n. 82) was published, Pierrette Hondagneu-Sotelo also spoke of a resurgence in paid domestic work in the US: "Regulating the Unregulated: Domestic Workers' Social Networks: Special Issue on Immigration, Race, and Ethnicity in America", Social Problems, 4I (1994), pp. 50-64. The same year, the Italian publisher Manifestolibri published a booklet entitled, significantly, Nuove servitù [New Servitudes]. Among the essays, that by André Gorz on the "new servants" (which built on his previous work) also spoke explicitly of the (growing) presence of domestic workers: "Perché la società del lavoro salariato ha bisogno di nuovi servi?”, in Marco Bascetta et al., Nuove servitù (Rome, I994), pp. 6I-70.

84. For instance Simone Odierna, Die heimliche Rückkehr der Dienstmädchen: Bezablte Arbeit im privaten Haushalt (Opladen, 2000); François-Xavier Devetter and Sandrine Rousseau, Du balai: Essai sur le ménage à domicile et le retour de la domesticité (Ivry-sur-Seine, 201 I).

85. Bridget Anderson, Britain's Secret Slaves: An Investigation into the Plight of Overseas Domestic Workers (London, 1993); http://www.antislavery.org; last accessed 20.1 2.2013; http:// www.kalayaan.org.uk/; last accessed 20.12.20I3. Later works by Anderson include the influential book Doing the Dirty Work? The Global Politics of Domestic Labour (London, 2000) and the volume, edited with Martin Ruhs, Who Needs Migrant Workers? Labour Shortages, Immigration and Public Policy (Oxford, 2010).

86. Dominique Torrès, Esclaves: 200 millions d'esclaves aujourd'bui (Paris, 1996). On the CCEM see http://www.esclavagemoderne.org/; last accessed 20.12.20I3.

87. Georgina Vaz Cabral, “Action nationale comparée de lutte contre l'esclavage moderne: Le cas particulier de l'esclavage domestique en Belgique, Espagne, France et Italie”, report presented for the Daphne Initiative JAH/98/DAF/215, Paris, I998, originally available at: http://www.esclavagemoderne.org/img_doc/daphne_ccem98.pdf (link no longer working); the text, without the name of the author and the title, is still available at: http://ec.europa. eu/justice_home/daphnetoolkit/files/projects/1998_21s/fr_legislations_nationales.pdf; an English translation without footnotes is available at: http://ccem.elteg.com/media/daphne_ccem98_uk.pdf; last accessed 02.06.20I4; Pino Arlacchi, Schiavi: Il nuovo traffico di esseri umani (Milan, I999); Kevin Bales, Disposable People: New Slavery in the Global Economy (Berkeley, CA, 1999); John Connor, "Domestic Slavery", Report for the Commission on Equal Opportunity for Men and Women, Parliamentary Assembly, Council of Europe, doc. 9102, Strasbourg, 200I; Joy M. Zarembka, "America's Dirty Work: Migrant Maids and Modern-Day Slavery", in Barbara Ehrenreich and Arlie 
has been particularly shocking since modernization had long been conceived as a process that would spread contractual (wage) labour. The definition of "modern" or "new" slavery addresses a complex phenomenon partially different from most forms of slavery in the past. A major difference is that in the past masters generally had legal rights over their slaves, while this is not the case with "modern" slavery, because legal slavery has been abolished all over the world. ${ }^{88}$ Exploitation and violence are instead common features of "old" and "new" slavery. So, while at the beginning of the twentieth century many people expected that domestic service would (soon) disappear, by the end of the century not only had there been a revival of paid domestic work but new forms of domestic slavery were also being denounced.

As mentioned above, domestic work in Europe and the US, particularly after World War II, had increasingly become a research field for historians rather than for sociologists, economists, anthropologists, etc. For several decades, social scientists almost ignored it. The (largely unexpected) "revival" of paid domestic and care work in the past three decades has prompted sociologists and other social scientists to focus on the issue, paying attention to its global dimension; to its relationship with the difficulties of welfare states; to its connection with the (growing) economic and demographic inequalities between the global north and the global south, and with the crisis of former communist countries in eastern Europe; to its role within international migration, human trafficking, and the growth of "modern" slavery; to the economic importance of remittances; to the spread of global care chains; to migration policies and the rights of migrants employed in domestic work; to the links between

Russel Hochschild (eds), Global Woman: Nannies, Maids and Sex Workers in the New Economy (New York, 2003), pp. I42-1 53; Francesco Carchedi, Giovanni Mottura, and Enrico Pugliese (eds), Il lavoro servile e le nuove schiavitù (Milan, 2003); Benedetto Bellesi and Paolo Moiola (eds), Il prezzo del mercato: Viaggio nelle nuove schiavitù (Bologna, 2006); Tiziana Bianchini (ed.), Nuove schiavitù: Fenomeni, strumenti e prospettive (Rome, 2006); Gianluca Ciampa, Il delitto di riduzione o mantenimento in schiavitù o servitù (Naples, 2008); Federica Resta, Vecchie e nuove schiavitù: Dalla tratta allo sfruttamento sessuale (Milan, 2008); E. Benjamin Skinner, A Crime So Monstrous: Face-to-Face with Modern-Day Slavery (New York, 2008); Silvia Angioi, Schiavitù e tratta: Antiche e nuove forme (Naples, 2010); Francesco Carchedi (ed.), Schiavitù di ritorno. Il fenomeno del lavoro gravemente sfruttato: Le vittime, i servizi di protezione, i percorsi di uscita, il quadro normativo, Dipartimento per le Pari Opportunità - Presidenza del Consiglio dei Ministri (Rimini, 20ı).

88. "The Parliamentary Assembly is dismayed that slavery continues to exist in Europe in the 2 Ist century. Although, officially, slavery was abolished over i 50 years ago, thousands of people are still held as slaves in Europe, treated as objects, humiliated and abused. Modern slaves, like their counterparts of old, are forced to work (through mental or physical threat) with no or little financial reward. They are physically constrained or have other limits placed on their freedom of movement and are treated in a degrading and inhumane manner"; Giuseppe Gaburro, "Domestic Slavery: Servitude, Au Pairs and Mail-Order Brides", Report for the Committee on Equal Opportunities for Women and Men, Parliamentary Assembly, Council of Europe, doc. I0.144, Strasbourg, 2004. 
former colonies and colonizer countries; to racialization and ethnicization processes; to the segregation of the labour market and the evolution of ethnic niches; to citizenship and rights; to unions and organizations of domestic workers; to policies to fight unemployment through the expansion of domestic and personal services; to new connections between private and public services; to the very identities and sociological profiles of domestic workers as far as gender, age, marital status, education, and skills are concerned; to their movements in and out of domestic work; to social mobility (upwards and downwards); to the features of families having recourse to domestic help; to the relationship of domestic workers both with their own families and with those of their employers; to cultural exchanges within the private household; and many other specific aspects. Hundreds of articles and books have been (and continue to be) published (see Figure 2). ${ }^{89} \mathrm{New}$ concepts and categories such as transnational motherhood, ${ }^{90}$ global care chains, ${ }^{91}$ contradictory class mobility, ${ }^{92}$ and feminization of survival ${ }^{93}$ have been elaborated in order to conceptualize the current features of paid domestic work and its global dimension.

89. Among influential studies focusing on the past decades which are not mentioned in other notes, see, for instance, Nicole Constable, Maid to Order: Stories of Filipina Workers (Cambridge, 1997), new revised edn: Maid to Order in Hong Kong: Stories of Migrant Workers (Ithaca, NY, 2007); Janet Henshall Momsen (ed.), Gender, Migration and Domestic Service (London, I999); Kathleen M. Adams and Sara Dickey (eds), Home and Hegemony: Domestic Service and Identity Politics in South and Southeast Asia (Ann Arbor, MI, 2000); Gul Ozyegin, Untidy Gender: Domestic Service in Turkey (Philadelphia, PA, 200I); Blandine Destremau and Bruno Lautier (eds), "Femmes en domesticité: Les domestiques du Sud, au Nord et au Sud", special issue of Tiers-Monde, 43 (2002); Annie Dussuet, Travaux de femmes: Enquêtes sur les services à domicile (Paris, 2005); Rosie Cox, The Servant Problem: The Home Life of a Global Economy (London [etc.], 2006).

90. Pierrette Hondagneu-Sotelo and Ernestine Avila, “'I’m Here, but I'm There': The Meaning of Latina Transnational Motherhood”, Gender and Society, I I (1997), pp. 548-57I. Later works by Pierrette Hondagneu-Sotelo include the influential volume, Doméstica: Immigrant Workers Cleaning and Caring in the Shadows of Affluence (Berkeley, CA, 200I).

91. Arlie Russel Hochschild, "Global Care Chains and Emotional Surplus Value", in Will Hutton and Anthony Giddens (eds), On the Edge: Living with Global Capitalism (London, 2000), pp. I30-I46; Rhacel Salazar Parreñas, Servants of Globalization: Women, Migration and Domestic Work (Stanford, CA, 200I).

92. Parreñas, Servants of Globalization, pp. I 50-196; "Migrant Filipina domestic workers define their sense of self and place in the global labour market from the contentious subjectposition of contradictory class mobility. This contentious location refers to their simultaneous experience of upward and downward mobility in migration. More specifically, it refers to their decline in social status [because they work abroad as maids, being often middle-class women in their own country] and increase in financial status [because salaries in countries where they work are higher than salaries in the Philippines]. This is the central dislocation that defines their experience of domestic work" (p. I 50).

93. Saskia Sassen, "Women's Burden: Counter-Geographies of Globalization and the Feminization of Survival”, Nordic Journal of International Law, 7I (2002), pp. $255^{-274}$. 
Possibly the most influential book in this field is Rhacel Parreñas's Servants of Globalization, which focuses on domestic workers from the Philippines in Rome and Los Angeles. Italy has rapidly changed from an emigration country to an immigration one, and has been characterized by limited welfare provision associated with growing female employment, by a failure to redistribute domestic tasks between men and women, and by a rapidly ageing population. Mainly thanks to this book and another important one, Jacqueline Andall's Gender, Migration and Domestic Service: The Politics of Black Women in Italy, ${ }^{94}$ the Italian case has become almost a paradigm of the possible consequences of new worldwide inequalities and new strategies of survival based on the exportation/ importation of care and global care chains. ${ }^{95}$

94. Jaqueline Andall, Gender, Migration and Domestic Service: The Politics of Black Women in Italy (Aldershot, 2000).

95. As mentioned, Italian scholars had begun early on to stress the growing presence of domestic workers, particularly of migrants; some of their contributions had impact outside Italy, too; others did not because they were written in Italian. See, for instance, Turrini, Le casalinghe di riserva; Erminio Crippa, Lavoro amaro: Le estere in Italia (Rome, 1979); Giovanna Campani, "Du Tiers-Monde à l'Italie: Une nouvelle immigration féminine”, Revue européenne de migrations internationales, 5 (1989), pp. 29-49; Claudia Alemani and Maria Grazia Fasoli, Donne in frontiera: Le colf nella transizione (Milan, I994); Maurizio Ambrosini, "Convenienze nascoste: L'inserimento degli immigrati nell'economia informale", Studi di sociologia, 36 (1998), pp. 233-257. The growth of scientific interest has paralleled the growth of immigration; see for instance Giuseppe Sciortino, "Immigration in a Mediterranean Welfare State: The Italian Experience in Comparative Perspective", Journal of Comparative Policy Analysis: Research and Practice, 6 (2004), pp. I I I-I 29. Among recent volumes (articles are too numerous to be listed) on domestic work by Italian scholars, sometimes in collaboration with non-Italian ones, see Jaqueline Andall and Raffaella Sarti (eds), "Servizio domestico, migrazioni e identità di genere in Italia dall'Ottocento a oggi", special issue of Polis: Ricerche e studi su società e politica in Italia, I 8 (2004); Francesca Decimo, Quando emigrano le donne: Percorsi e reti femminili della mobilità transnazionale (Bologna, 2005); Sergio Pasquinelli and Giselda Rusmini, Badanti. La nuova generazione: Caratteristiche e tendenze del lavoro privato di cura (Milan, 2008); Paola Bonizzoni, Famiglie globali: Le frontiere della maternità (Turin, 2009); Raimondo Catanzaro and Asher Colombo (eds), Badanti \& Co: Il lavoro domestico straniero in Italia (Bologna, 2009) (the volume presents the results of research funded by the Italian Ministry for University and Scientific Research on "Nationality, Gender and Class in the New Domestic Service. Changes in the Italian Family and Evolution of Migratory Systems"); Francesca Alice Vianello, Migrando sole: Legami transnazionali tra Ucraina e Italia (Milan, 2009); Sabrina Marchetti, "Paid Domestic Labour and Postcoloniality: Narratives of Eritrean and Afro-Surinamese Migrant Women” (Ph.D., Utrecht University, 2010); Barbara Da Roit and Carla Facchini, Anziani e badanti: Le differenti condizioni di chi è accudito e di chi accudisce (Milan, 20Io); Raffaella Sarti and Francesca Scrinzi (eds), “Men in a Woman's Job: Male Domestic Workers, International Migration and the Globalization of Care", special issue of Men and Masculinities, I3 (2010); Francesco Vietti, Il paese delle badanti (Rome, 2010); Elisabetta Zontini, Transnational Families, Migration and Gender: Moroccan and Filipino Women in Bologna and Barcelona (New York, 2010); Sabrina Marchetti, Le ragazze di Asmara: Lavoro domestico e migrazione postcoloniale (Rome, 20I I); Paolo Boccagni and Maurizio Ambrosini, Cercando il benessere nelle migrazioni: L'esperienza delle assistenti familiari straniere in 


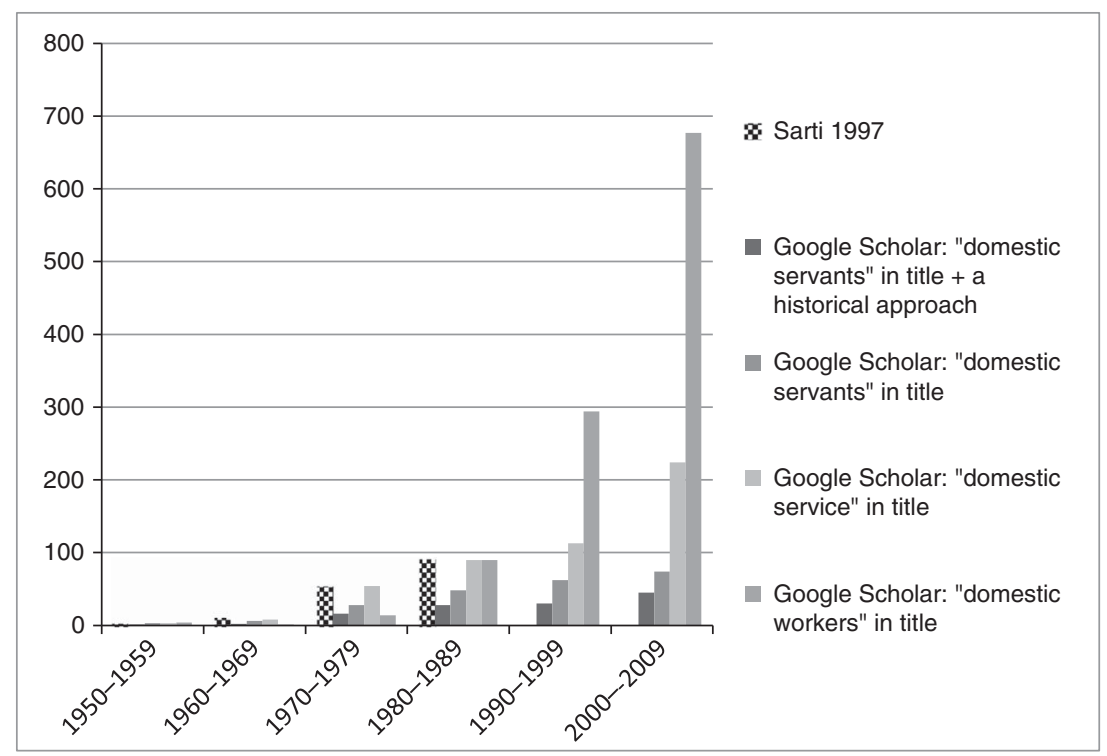

Figure 2. Studies on domestic service published between 1950 and 2009 (an approximation). ${ }^{96}$ Raffaella Sarti, "Il servizio domestico come problema storiografico", Storia e Problemi Contemporanei, 20 (1997), pp. I59-184; Google Scholar (March 20I3).

\section{NEW OPPORTUNITIES FOR EXCHANGE}

In the I970s-I980s, as previously mentioned, domestic service was almost ignored by sociologists and other social scientists focusing on Europe and the US. Instead, it was investigated by some scholars who conducted

Trentino (Milan, 20I2); Colf d'Italia: I50 anni di lavoro domestico per raccontare l'Italia che cura, Atti del convegno, I8 novembre 20II, Roma (Rome, 20I2); Flavia Piperno and Mara Tognetti Bordogna (eds), Welfare transnazionale: La frontiera esterna delle politiche sociali (Rome, 2012); Sergio Pasquinelli and Giselda Rusmini (eds), Badare non basta: Il lavoro di cura: attori, progetti, politiche (Rome, 20I3); Maurizio Ambrosini, Irregular Migration and Invisible Welfare (Basingstoke, 2013); Francesca Scrinzi, Genre, migrations et emplois domestiques en France et en Italie: Construction de la non-qualification et de l'altérité ethnique (Paris, 2013); Sabrina Marchetti, Black Girls: Migrant Domestic Workers and Colonial Legacies (Leiden, 2014, forthcoming).

96. Books and articles with titles including the words "domestic service" but which do not deal with domestic work have not been considered. The aim of Figure 2 is to give an approximate idea of the growing production of research that deals with domestic service. Since scholars focusing on the present generally (and correctly) speak of domestic workers rather than domestic servants, the column "domestic workers" in particular gives an idea of the boom in production of articles and books by sociologists and other social scientists. Obviously, the data and method used to create Figure 2 are rather rough and the results have many biases: interrogating Google Scholar, I have considered only texts written in English; many texts which deal with domestic service, domestic servants, or domestic workers do not have these words in the title; texts written in recent years are more likely to be listed by Google Scholar; etc. 
research on Latin America, Africa and Asia. ${ }^{97}$ Here, as had been the case in Europe and the US in the nineteenth and beginning of the twentieth centuries, there was some dialogue between historians, sociologists, and social scientists. Furthermore, a knowledge of history was considered necessary in order to change or improve domestic workers' conditions in the present (through, for instance, new organizations and unions), and there were also connections between scholars and activists..$^{98}$

The "revival" of paid domestic work and its "(re)discovery" by social scientists have brought about new opportunities for exchange between them and historians, as well as between scholars and activists worldwide. Some arenas for discussion have developed. Seminars, workshops, sessions of congresses, and conferences, both at national and international level, have offered opportunities for meeting and exchange. Some international meetings especially deserve to be mentioned. ${ }^{99}$

The round table "La Phénomène de la Domesticité en Europe, XVIe-XXe centuries", organized in Prague in 1996 by Antoinette Fauve-Chamoux and Ludmila Fialová, though mainly involving demographers and historians and focusing on Europe, was possibly the starting point of a networking activity that in the succeeding years would link scholars with different backgrounds and research interests, and from many different countries and continents, as well as some unionists and activists. ${ }^{100}$ In particular, it was the origin of one big network, the Servant Project, funded by the European Commission, which was to connect some twenty European universities and research centres and to organize five main conferences and some minor meetings between 2002 and 2004, with the participation of about eighty scholars. ${ }^{\text {IOI }}$ Among the participants in the

97. For instance, Whisson and Weil, Domestic Servants; Rutté García, Simplemente explotadas. 98. For instance, the volume by Chaney and Castro, Muchachas No More, includes a section on domestic service in the past, with three chapters: Elizabeth Kuznesof, "A History of Domestic Service in Spanish America, I492-1980", pp. 17-35; Barry W. Higman, "Domestic Service in Jamaica since 1750", pp. 37-66; Sandra Lauderdale Graham, "Servants and Masters in Rio de Janeiro: Perceptions of House and Street in the I870s", pp. 67-80; moreover, within Part 5, "In Their Own Words: Testimonies of Workers", there is a chapter by Aída Moreno Valenzuela on the "History of the Household Workers' Movement in Chile, I926-1983", pp. 407-4I 5. Other examples of books and articles which deal with both past and present are Lesley Gill, Precarious Dependencies: Gender, Class and Domestic Service in Bolivia (New York, 1994); Jacklyn Cock, Maids E Madams: A Study in the Politics of Exploitation (Johannesburg, 1980), which also includes a historical chapter, and the article by Deborah Gaitskell, Judy Kimble, Moira Maconachie, and Elaine Unterhalter, "Class, Race and Gender: Domestic Workers in South Africa”, Review of African Political Economy, io (1983), pp. 86-108.

99. I list only international conferences where both historians and social scientists were present. I do not list sessions and panels in congresses, which are too numerous to be mentioned.

ı०o. Fauve-Chamoux and Fialová, Le phénomène de la domesticité.

I0I. The application for the "Servant Project" was prepared by Antoinette Fauve-Chamoux, Raffaella Sarti, Suzy Pasleau, and Isabelle Schopp. The official title of the project was "The 
network were Regina Schulte and Pothiti Hantzaroula, who in 2000 had organized the workshop "Narratives of the Servant" at the European University Institute in Florence in 2000. ${ }^{102}$

A preliminary meeting of participants in the Servant Project was held in Brussels, during the conference "Bonnes pour le service. Déclin, professionnalisation et émigration de la domesticité, Europe, Canada, 2oe siècle" (13-Is December 200I), organized by Eliane Gubin and Valérie Piette. ${ }^{103}$ Some months earlier, in February 200I, another meeting took place, the conference "Domestic Service and Mobility: Labour, Livelihoods and Lifestyles", organized in Amsterdam by Ratna Saptari and Annelies Moors and mainly focusing on Asia. ${ }^{104}$ Among the participants at both this conference and the Servant Project was Helma Lutz, who in 2005 would coordinate the conference "Migration and Domestic Work in Global Perspective" held at the NIAS (Netherlands Institute for Advanced Studies). ${ }^{\text {Ios }}$

Socio-Economic Role of Domestic Service as a Factor of European Identity”, with the main conferences taking place in Florence (I 4-I 6 February 2002), Oslo (I $3-15$ June 2002), Barcelona (I 2-Is December 2002), Essex (8-10 May 2003), and Munich (8-II September 2003). See Fauve-Chamoux, Domestic Service and the Formation of European Identity; Pasleau and Schopp, with Sarti, Proceedings of the Servant Project. I: Servants and Changes in Mentality, 16th-2oth Centuries; II: Domestic Service and the Emergence of a New Conception of Labour in Europe; III: Domestic Service and the Evolution of the Law; IV: Domestic Service as a Factor of Social Revival in Europe; V: The Modelization of Domestic Service. For the conclusion of the project see Sarti, "Conclusion: Domestic Service and European Identity".

I02. Regina Schulte and Pothiti Hantzaroula (eds), "Narratives of the Servant", European University Institute, EUI Working Papers, Florence, 200I. On Schulte's production on domestic service see n. 63 ; by Pothiti Hantzaroula see, besides several articles, her Ph.D. thesis: "The Making of Subordination: Domestic Servants in Greece, 1920-I945" (Ph.D., EUI, Department of History and Civilization, 2002).

I03. Eliane Gubin and Valérie Piette (eds), "Domesticité", special issue of Sextant, $25-26$ (200I). On Piette's production see n. I3.

I04. "Domestic Service and Mobility: Labour, Livelihoods and Lifestyles", CLARA (Changing Labour Relations in Asia) and University of Amsterdam, International Institute of Social History, 5-7 February 200I. The proceedings of the conference were not published. The publications on domestic service by Ratna Saptari include "Rethinking Domestic Service", International Review of Social History, 44 (1999), pp. 77-85; "Studying Asian Domestics Within Global Processes: Comparisons and Connections", in Jan Lucassen (ed.), Global Labour History: A State of the Art (Bern, 2006), pp. 479-5 I 2; "Servant Problems: Regulation, Boundary Work and Trans-Border Links", International Review of Social History, 54 (2009), pp. 275-286; those by Annelies Moors include "Migrant Domestic Workers: Debating Transnationalism, Identity Politics, and Family Relations: A Review Essay", Comparative Studies in Society and History, 45 (2003), pp. 386-394; idem and Marina de Regt, "Migrant Domestic Workers in the Middle East", in Marlou Schrover, Joanne van der Leun, Leo Lucassen, and Chris Quispel (eds), Illegal Migration and Gender in a Global and Historical Perspective (Amsterdam, 2008), pp. I I I-I 70 .

I05. The conference was financed by the Volkswagen Foundation as part of the research project coordinated by Helma Lutz on "Gender, Ethnicity and Identity: The New Maids in the Age of Globalisation”. Many papers presented at the conference were published in Helma 
Another scholar involved in this networking was Carolyn Steedman, who, in 2008, organized the conference "Waged Domestic Work and the Making of the Modern World" at the University of Warwick. ${ }^{\text {Io6 }}$ A month before, with the participation of some scholars involved in the meetings already listed as well as several others, another conference took place: "À qui me confier? Du monde des nourrices aux réseaux des 'mamans de jour': Pratiques et enjeux de la garde d'enfants", organized in Freiburg, Switzerland, by Véronique Pach and Véronique Dasen (2008). ${ }^{107}$ Among the conferences that have been held outside Europe, it seems to me that the conference on "Intimate Labors" in Santa Barbara, California, the proceedings of which have been published by Eileen Boris and Rhacel Parreñas, ${ }^{108}$ was particularly productive of exchanges, while the conference held in Newcastle (Australia) by Victoria Haskins in 2012 addressed the crucial issue of "Colonization and Domestic Service". ${ }^{\circ 99}$ An international workshop with the participation of scholars looking at the idea of the servant from different perspectives, entitled

Lutz (ed.), Migration and Domestic Work: A European Perspective on a Global Theme (Aldershot, 2008). Lutz is the author of several studies on domestic work; see especially idem, Vom Weltmarkt in den Privathaushalt: Die newen Dienstmädchen im Zeitalter der Globalisierung (Leverkusen, 2007), Engl. transl.: The New Maids: Transnational Women and the Care Economy (London, 20I I).

I06. "Waged Domestic Work and the Making of the Modern World", Conference, University of Warwick, 9-I I May 2008. The proceedings were not published. Books on domestic service by Carolyn Steedman include Master and Servant (Cambridge, 2007); Labours Lost: Domestic Service and the Making of Modern England (Cambridge, 2009).

I07. "À qui me confier? Du monde des nourrices aux réseaux des 'mamans de jour': Pratiques et enjeux de la garde d'enfant”, Fribourg, 23-25 April 2008; for the proceedings see Véronique Pache Huber and Véronique Dasen (eds), "Politics of Child Care in Historical Perspective: From the World of Wet Nurses to the Networks of Family Child Care Providers", special issue of Paedagogica Historica, 46 (2010). On Pache Huber's production see n. 32. Annelies Head Koenig, who had a responsibility role within the Servant Project, was one of the scholars who also took part in the Freiburg conference, to mention one example.

I08. "Intimate Labors. An Interdisciplinary Conference on Domestic, Care, and Sex Work", University of California, Santa Barbara, 4-6 October 2007; for the programme see: http:// www.ihc.ucsb.edu/intimatelabors/downloadable_schedule.pdf; last accessed 20.12.20I3; for the proceedings see Eileen Boris and Rhacel Salazar Parreñas (eds), Intimate Labors: Care, Sex, and Domestic Work (Stanford, CA, 2010). On Parreñas see n. 9I; the long list of publications by Eileen Boris includes the recent volume with Jennifer Klein, Caring for America: Home Health Workers in the Shadow of the Welfare State (Oxford, 2012).

I09. "Colonization and Domestic Service: Historical and Contemporary Perspectives", Research Symposium, Newcastle, I6-I7 July 2012; for the programme see: http://www.newcastle.edu.au/

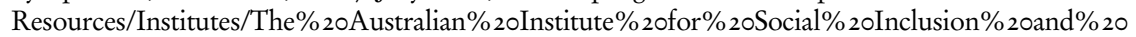
Wellbeing/Seminars/Colonization \% 20and\% 20Domestic\% 20Services_Program\% 20Final_web.pdf; last accessed 20.12.20I3. Works by Victoria Haskins on the history of domestic service include several articles on Australia, such as "On the Doorstep: Aboriginal Domestic Service as a 'Contact Zone'”, Australian Feminist Studies, I6 (200I), pp. I3-25, and the volume Matrons and Maids: Regulating Indian Domestic Service in Tucson, 19I4-I934 (Tucson, AZ, 2012). 
"In Pursuit of Invisible Forces: Servants in History and Today", was organized in 2009 at the Humanities Center at Harvard University by Markus Krajewski. ${ }^{\text {IIO }}$

Exchanges among scholars with different backgrounds are not always easy, but they are necessary if we want to understand what is really new with "new" domestic work and what is actually a "resurgence" or a "revival" of "old" features. For instance, the presence of international migrant domestic workers, male and female, is not a modern novelty, even though the phenomenon of international migration of domestic workers has by now probably reached unprecedented levels. ${ }^{\text {II I }}$ In several contexts, the growth of "new" domestic work has involved the expansion of arrangements that were long considered "old", "traditional", and not appropriate in "modern" societies, such as, in particular, the co-residence of employers and employees under the same roof. ${ }^{112} \mathrm{~A}$ point in case here is gender, which has played such an important role in research on domestic service. As previously mentioned, feminization of domestic staff was often considered a feature of the stages before the (alleged) final phase in the evolution of domestic service, i.e. its disappearance. A feminization of domestic personnel took place, indeed, in many different countries, particularly in the nineteenth and twentieth centuries. ${ }^{I I 3}$ Significantly, however, in recent decades paid domestic work has

I I0. Markus Krajewski (ed.), Master and Servant in Technoscience, special issue of Interdisciplinary Science Reviews, 37 (2012). Publications by Krajewski include Der Diener: Mediengeschichte einer Figur zwischen König und Klient (Frankfurt a. Main, 2010).

I I I. For an overview see Raffaella Sarti, "The Globalisation of Domestic Service: An Historical Perspective", in Lutz, Migration and Domestic Work, pp. 77-98, also published in French in a longer version: "La globalisation du service domestique dans une perspective historique, XVIIe-XXe siècles", in Manuela Martini and Philippe Rygiel (eds), Genre et travail migrant: Mondes atlantiques, XIXe-XXe siècles (Paris, 2009), pp. 53-82. Among books and chapters (also) dealing with this issue, see for instance: Leslie Page Moch, Moving Europeans: Migrations in Western Europe since 1650 (Bloomington, IN, 1992); Sølvi Sogner, "Young in Europe around 1700: Norwegian Sailors and Servant-Girls Seeking Employment in Amsterdam”, in Jean-Pierre Bardet, François Lebrun, and René Le Mée (eds), Mesurer et comprendre: Mélanges offerts à Jacques Dupâquier (Paris, I993), pp. 515-532; Dirk Hoerder and Leslie Page Moch (eds), European Migrants: Global and Local Perspectives (Boston, MA, 1996); Anne-Lise HeadKönig, "The Foreign Labour Force in Urban Switzerland: Immigration and Marriage Patterns of Female Servants in the Nineteenth and Early Twentieth Centuries", in René Leboutte (ed.), Migrations et Migrants dans une perspective historique: Permanences et innovations/Migrations and Migrants in Historical Perspective: Permanencies and Innovations (Brussels [etc.], 2000), pp. 77-96; Sylvia Hahn, Migration - Arbeit - Geschlecht: Arbeitsmigration in Mitteleuropa vom 17. bis zum Beginn des 20. Jahrhunderts (Göttingen, 2008); Margaret Lynch-Brennan, Irish Immigrant Women in Domestic Service in America, 1840-1930 (Syracuse, NY, 2009); Dirk Hoerder and Amarjit Kaur (eds), Proletarian and Gendered Mass Migrations: A Global Perspective on Continuities and Discontinuities from the 19th to the 21st Centuries (Leiden, 2013).

I 12. For example Sarti, "The Globalisation of Domestic Service”.

II 3. For comparative data see, for instance, Raffaella Sarti, "Notes on the Feminization of Domestic Service: Bologna as a Case Study (I8th-19th centuries)”, in Fauve-Chamoux and 
experienced not only a revival (instead of a decline) but also, in some contexts, a (slight) re-masculinization. ${ }^{\mathrm{II} 4}$

Obviously, strengthening the dialogue between historians and social scientists does not simply mean supplying scholars working on the present with information and data on the events of the past; it also (and more fruitfully) means developing new interpretative frameworks after the rejection of the old paradigms that have proven limited or wrong. "Throughout the twentieth century, domestic service had a compelling presence in British economic, social, and cultural life", Lucy Delap recently argued, moving away from previous interpretations of the history of domestic service in twentieth-century Britain, which considered it to be a declining phenomenon. ${ }^{\text {If }}$ However we view her interpretation (praising or criticizing it), it constitutes an interesting example of changing paradigms.

\section{CONCLUSION: TOWARDS A GLOBAL HISTORY OF DOMESTIC SERVICE}

As I have shown, a huge amount of research has been done on the history of domestic service in many different places and periods. Certainly, there still are contexts for which research (or at least research accessible to scholars with knowledge of western European languages only) seems to be limited, such as, for instance, Russia (where domestic workers did not disappear after the Russian Revolution), ${ }^{116}$ and the former European

Fialová, Le Phénomène de la domesticité, pp. I25-163; idem, "Domestic Service: Past and Present in Southern and Northern Europe", Gender and History, I 8 (2006), pp. 222-245; José C. Moya, "Domestic Service in a Global Perspective: Gender, Migration, and Ethnic Niches", Journal of Ethnic and Migration Studies, 33 (2007), pp. 559-579. For another interesting case that questions the modernization paradigm see Isidro Dubert, "Modernity without Modernisation: The Evolution of Domestic Service in North-West Spain, 1752-1900", Gender E History, I8 (2006), pp. 199-2 I0.

I I4. On this re-masculinization and male domestic workers see Sarti, "Domestic Service: Past and Present", pp. 232-235; Francesca Scrinzi, "Les hommes de ménage, ou comment aborder la féminisation des migrations en interviewant des hommes", Migrations Société, I7 (2005), pp. 229-240; Sarti and Scrinzi, "Men in a Woman's Job”, special issue of Men and Masculinities, I 3 (2010), including Sarti, "Fighting for Masculinity"; Francesca Scrinzi, "Masculinities and the International Division of Care: Migrant Male Domestic Workers in Italy and France", pp. 44-64; Lena Näre, "Sri Lankan Men Working as Cleaners and Carers: Negotiating Masculinity in Naples", pp. 65-86; Bartolomei, "Migrant Male Domestic Workers”; Qayum and Ray, "Male Servants and the Failure of Patriarchy in Kolkata"; Majella Kilkey, "Men and Domestic Labor: A Missing Link in the Global Care Chain", pp. I26-I49. See also Majella Kilkey, Diane Perrons, and Ania Plomien, Gender, Migration and Domestic Work: Masculinities, Male Labour and Fathering in the UK and US (Basingstoke, 2013).

I I s. Delap, Knowing their Place, p. I.

I I6. Rebecca Spagnolo, "When Private Home Meets Public Workplace: Service, Space and the Urban Domestic in I920s Russia", in Eric Naiman and Christina Kaier (eds), Everyday Life in Early Soviet Russia: Taking the Revolution Inside (Bloomington, IN, 2006), pp. 230-255. 
socialist countries, or China. ${ }^{117}$ However, those studies already available, as well as the many others under way, constitute a good starting point for a new global history of domestic service. ${ }^{\mathrm{II} 8}$ This also implies, for the future, a discussion of what global history could, or should, mean in relation to domestic service. ${ }^{\text {II9 }}$ Could or should a new specific theoretical framework be developed?

The answer cannot be simple, particularly if we consider that, in the case of domestic service, comparison over time and place raises very serious methodological problems. Domestic service has always been a very difficult research subject because its boundaries are not well defined. ${ }^{120}$ Yet the broadening of the research field and arena for comparisons to a global level sharpens the problem and constitutes a challenge for the whole field.

A century ago, some historical studies had been written to contribute to a better future: a future without any kind of servants or, at least, with domestic workers enjoying dignity and rights. Instead, today many domestic workers still suffer because of stigmatization, poor working conditions, low salaries, a lack of dignity and rights, and even worse. It was only in 20I I that the ILO (International Labour Organization) eventually approved Convention 189 on decent work for domestic workers: ${ }^{12 \mathrm{I}}$ a success on the one hand, a sad confirmation of the persistence of bad working and living conditions for domestic workers on the other. Unfortunately,

I17. Man Guo, "Migration Experience of Floating Population in China: A Case Study of Women Migrant Domestic Workers in Beijing” (M.Phil. thesis, University of Hong Kong, 2006); Yan Hairong, New Masters, New Servants: Migration, Development, and Women Workers in China (Durham, NC, 2008); Li Shuang, "Employées domestiques en Chine: Les implications de la hiérarchie urbain/rural”, in Tania Angeloff and Marylène Lieber (eds), Chinoises au XXIè siècle: Ruptures et continuités (Paris, 20I2), pp. I $2 \mathrm{I}-\mathrm{I} 38$.

I 18. For some efforts in this direction see, for instance, Moya, "Domestic Service in a Global Perspective"; Sarti, "The Globalisation of Domestic Service”.

I19. See, for instance, the discussion of the meaning of global history of labour by Marcel van der Linden, Workers of the World: Essays toward a Global Labor History (Leiden, 2009), pp. 6-I3. Here he puts forward a series of (provisional) definitions and research questions which can also serve as guide for discussions among scholars working on domestic service.

I20. Raffaella Sarti, "Who are Servants? Defining Domestic Service in Western Europe (I6th-2 Ist Centuries)", in Pasleau and Schopp, with Sarti, Proceedings of the Servant Project, II, pp. 3-59, available at: http://www.uniurb.it/sarti/3.\% 20Raffaella\%20Sarti-Who\% 20are\% 20servants-Proceedings \% 20of\% 20the\% 20Servant\% 20Project-Final\% 20Version.pdf; last accessed 20.12.2013. Among later articles see, for instance, Lotta Vikström, "Aspects of Women's Work in Sundsvall, Sweden, I860-1893", in Harvey J. Graff, Alison Mackinnon, Bengt Sandin, and Ian Winchester (eds), Understanding Literacy in Its Historical Contexts: Socio-Cultural History and the Legacy of Egil Johansson (Lund, 2009), pp. I27-I42.

I 2 I. Convention Concerning Decent Work for Domestic Workers, International Labour Organization Convention No. I 89, Geneva, 20I I, available at: http://www.ilo.org/dyn/normlex/en/f?p= NORMLEXPUB:I 2 I00:0::NO::Pi 2 I00_INSTRUMENT_ID:255 I460; last accessed 20.1 2.20I 3 . 
there is still a need for such a convention; combating the lack of rights and dignity is still on the agenda. ${ }^{\mathrm{I2}}$

Collaborations between scholars and activists can, one hopes, contribute to overcoming the current situation. Historical research has shown that servants and domestic workers have been fighting for their rights for at least a couple of centuries. Formal recognition of rights generally arrived (where it has in fact arrived) ${ }^{\mathrm{I} 23}$ later than for many other workers; at the same time, when formal rights were introduced, they often were, and still are, disregarded or have not always entailed real empowerment of domestic workers. ${ }^{24}$

"Domestic work is work. Domestic workers are, like other workers, entitled to decent work", a brochure of the ILO maintains, while describing Convention I89. ${ }^{\text {I25 }}$ More than 200 years ago, domestiques and other persons claiming rights for domestics during the French Revolution also argued that they were workers: ${ }^{26}$ why is there still a need today to make the argument that domestic workers are workers? Some scholars suggest that this has to do with the particular place where domestic work is performed, i.e. the private household, and/or with the very characteristics of domestic work. For a long time, domestic work has been frequently singled out so as to exclude domestic workers from enjoying rights and protective legislation. ${ }^{127}$

I22. For instance, Franck Bailly, François-Xavier Devetter, and François Horn, "Can Working and Employment Conditions in the Personal Services Sector Be Improved?", Cambridge Journal of Economics, 37 (2013), pp. 299-321.

I23. Hildete Pereira de Melo, O serviço doméstico remunerado no Brasil: de criadas a trabalhadoras, (Rio de Janeiro [etc.], I998), pp. I 5-17, available at: https://sistema.planalto.gov.br/ spmulheres/textos/DOMINIO\% 20PUBLICO/td_0565.pdf; last accessed 20.1 2.2013.

I 24. For instance, Sheireen A. Ally, From Servants to Workers: South African Domestic Workers and the Democratic State (Ithaca, NY, 2009); Raffaella Sarti (ed.), Lavoro domestico e di cura: quali diritti? (Rome, 2010).

I 25. International Labour Organization, "Convention No. I89: Decent Work for Domestic Workers”, Geneva, n.d., p. I, available at: http://www.ilo.org/wcmsps/groups/public/-ed_protect/-protrav/_travail/documents/publication/wcms_i6r I I04.pdf; last accessed 20.1 2.2013.

I 26. See for instance "Pétition des domestiques (28 August 1792)", in Archives Parlementaires de I787 à I 860: Recueil complet des débats législatifs et politiques des Chambres françaises, Première série, 1787 à 1799 (Paris, I867), L, pp. 671-672. See Sarti, "Who are Servants?”, pp. I8-26; idem, "Freedom and Citizenship? The Legal Status of Servants and Domestic Workers in a Comparative Perspective (I6th-2 Ist Centuries)", in Pasleau, Schopp, with Sarti, Proceedings of the Servant Project, III, pp. I27-I64, available at: http://www.uniurb.it/sarti/Raffaella\% 20 SartiFreedom $\%$ 20and $\%$ 20Citizenship-Proceedings $\%$ 20of $\%$ 20the $\%$ 20Servant $\%$ 20Project.pdf); last accessed 20.12.20I3; idem, "Servo e/o cittadino? Il dibattito sui diritti politici dei domestici durante la Rivoluzione francese", in Glauco Maria Cantarella, Angela De Benedictis, Patrizia Dogliani, Carla Salvaterra, and Raffaella Sarti (eds), Potere e violenza: Concezioni e pratiche dall'antichità all'età contemporanea (Rome, 20I 2), pp. 7I-93.

I27. See e.g. Sarti, "Freedom and Citizenship?"; idem, "Conclusion: Domestic Service and European Identity", pp. 242-247. 


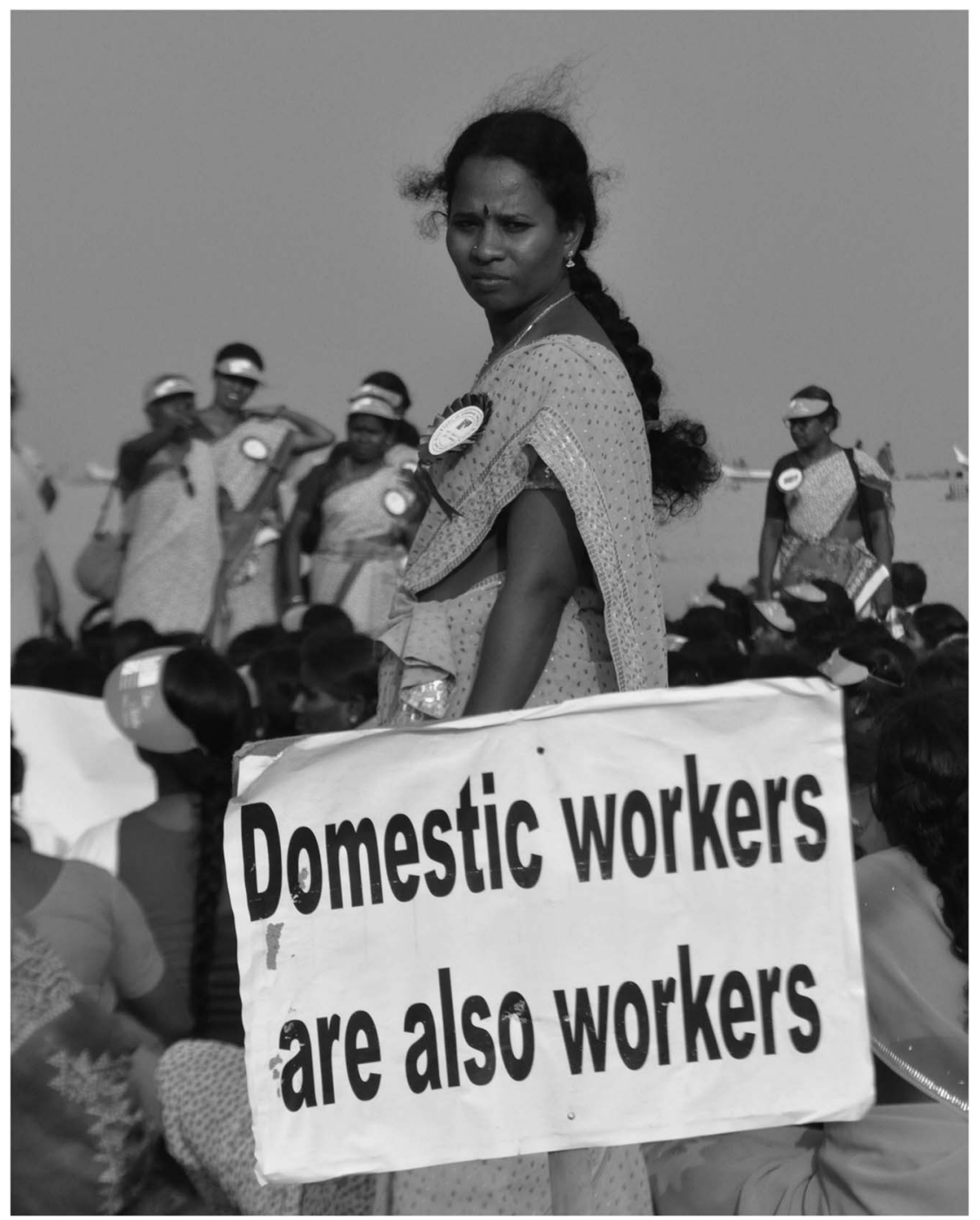

Figure 3. Around 4,000 domestic workers gathered in 2010 on Marina Beach in Chennai, capital of the Indian state of Tamil Nadu, demanding dignity for their work and life. The picture is the result of a photographic competition organized by the International Labour Office, New Delhi branch, to promote decent work for domestic workers.

Photograph: S.P. Ouseph (C) International Labour Organization. Used with permission.

Within the current debate it is often taken into account in order to (possibly) improve their conditions. Some scholars, for example, believe that, since many domestic workers are migrants, "portable rights" should 
be expanded; ${ }^{\mathrm{I} 28}$ some suggest a "creolization" of rights; ${ }^{\mathrm{I} 29}$ some propose the developments of transnational welfare. ${ }^{130}$ These issues cannot be discussed in an essay of this length. In my view, the extension of universal rights to domestic workers is certainly necessary, but evidence shows that it is not always sufficient to change their working conditions radically. Thus, it seems to me that the question of rights and entitlements, in order to be resolved, needs comparisons over time and space from many different perspectives, and requires the expertise of historians, economists, sociologists, anthropologists, psychologists, jurists, unionists, activists, and, obviously, domestic workers themselves, as well as their employers. As such, it constitutes, in my view, an arena for fruitful comparisons at both academic and policy making levels. Within such an arena historians bear responsibility for supplying evidence about past experiences which can contribute to the elaboration of new interpretations and new tools, possibly contributing to a more just future. ${ }^{\mathrm{I}}{ }^{\mathrm{I}}$ What is needed is a global history of domestic service and domestic work, because domestic work had a global dimension in the past and possibly has even more of one today.

At the same time, the once common forecasts of, and hopes for, the disappearance of domestic service and (even) paid domestic work should not be forgotten. As mentioned, I am interested in studying them and in understanding why they have proven inadequate or wrong for both scientific and political reasons. In my view, the question formulated by Joan Tronto years ago, "Are there alternatives to hiring domestic

I 28. Sakia Sassen, "The Limits of Power and the Complexity of Powerlessness: The Case of Immigration I", Unbound, 3 (2007), pp. I05-1 16; Encarnación Gutiérrez-Rodríguez, Migration, Domestic Work and Affect: A Decolonial Approach on Value and the Feminization of Labour (New York, 2010), pp. I55-156.

I29. Encarnación Gutiérrez-Rodríguez, Migration, Domestic Work and Affect: A Decolonial Approach on Value and the Feminization of Labour (New York, 2010), pp. 148-169; she comments, "Creolizing human rights [...] evokes a cosmological perception of rights, one that attaches rights not to a single individual or subject, but to the relationship of this individual or subject to others and his/her environment. From this angle, human rights cannot depart from the separation between the Self and the Other or the Human and the Environment. Rather, it engages with an ethics of relationality and transversality [...]. Thus, framing domestic workers' rights from the perspective of creolizing human rights entails more than just fighting for fair working conditions or professionalization of domestic work. Rather, it interconnects domestic work as affective labor to a cosmological perspective, uncovering it as the main source for the production and maintenance of human vitality, the sustenance of 'perpetual life'. Further, it urges us to locate this labor within a collective framework of sustainability and transversal conviviality, departing from a decolonial ethics of affects" (p. 164).

I30. Piperno and Tognetti Bordogna, Welfare transnazionale.

I3I. The issue of a lack of equality is at the centre of a recent issue of the Revista de Estudios Sociales: Lorena Poblete and Ania Tizziani (eds), "Servicio doméstico y desigualdad social", Revista de Estudios Sociales, 45 (2013). 
servants?", is still relevant and should be addressed by the scholars involved. Do we still want to contribute to giving a positive answer to it? ${ }^{\mathrm{I} 32}$

\author{
TRANSLATED ABSTRACTS \\ FRENCH - GERMAN - SPANISH
}

Raffaella Sarti. Historiens, spécialistes en sciences sociales, serviteurs et travailleurs domestiques: cinquante années de recherche sur le travail et les soins domestiques.

$\mathrm{La}$ recherche historique sur les serviteurs domestiques a une longue tradition. Toutefois, cette recherche est devenue plus systématique à partir des années 1960 grâce aux historiens de l'histoire sociale, aux historiens se consacrant principalement à l'histoire de la famille, aux démographes historiens et, particulièrement à partir des années 1970, aux historiens des femmes et du genre. Longtemps, les chercheurs ont supposé que le service domestique (notamment en résidant chez l'employeur) déclinerait ou même disparaîtrait à cause de la modernisation des ménages, du progrès social et de l'évolution de l'État-providence. Ces trois dernières décennies, la "renaissance" (largement imprévue) du travail et des soins domestiques rémunérés a incité des sociologues et d'autres chercheurs des sciences sociales à étudier ce thème, ce qui a ouvert de nouvelles possibilités d'échange entre les historiens et les chercheurs des sciences sociales. Cet article présente un aperçu de la recherche mondiale sur les sujets évoqués, même si l'accent est mis sur l'Europe et les (anciennes) colonies européennes au cours des cinquante dernières années, en illustrant les différentes approches et leurs résultats.

Traduction: Christine Krätke-Plard

Raffaella Sarti. Historiker, Sozialwissenschaftler, Diener und Hausarbeiterinnen: fünfzig Jahre Forschung zur Haus- und Pflegearbeit.

Die historische Forschung zu Dienstboten hat eine lange Tradition. Seit den I96oer Jahren hat diese Forschung allerdings einen systematischeren Charakter angenommen, was Sozial- und Familienhistorikern, historischen Demographen sowie (insbesondere seit den I970er Jahren) Forscher und Forscherinnen aus den Bereichen der Frauen- und Geschlechtergeschichte zu danken ist. Lange Zeit gingen Wissenschaftler und Wissenschaftlerinnen davon aus, dass sich der Haushaltsdienst (insbesondere wenn die Hausbediensteten im Haushalt wohnen) aufgrund der Modernisierung der Haushalte, des sozialen Fortschritts und der Entwicklung des Wohlfahrtsstaats zurückentwickeln oder sogar gänzlich verschwinden würde. Die während der vergangenen drei Jahrzehnte zu verzeichnende (und weitgehend unerwartete) "Wiederkehr" der bezahlten Haus- und Pflegearbeit hat Soziologen und andere Sozialwissenschaftler und Sozialwissenschaftlerinnen angeregt, sich auf

I32. Joan C. Tronto, “The 'Nanny' Question in Feminism”, Hypatia, I7 (2002), pp. 34-5I. There are stimulating insights in Tronto's new book, Caring Democracy: Markets, Equality, and Justice (New York, 2013). 
das Thema zu konzentrieren, was neue Möglichkeiten des Austauschs zwischen Historikerinnen und Sozialwissenschaftlern eröffnet hat. Der Artikel bietet einen weltweiten, wenn auch auf Europa und die (ehemaligen) Kolonien fokussierten Überblick über die Forschung, die in den vergangenen fünfzig Jahren zu den genannten Themen entstanden ist und veranschaulicht die verschiedenen Ansätze sowie ihre Ergebnisse.

Übersetzung: Max Henninger

Raffaella Sarti. Historiadores, cientificos sociales, sirvientes y trabajadores/trabajadoras doméstico/as. 50 años de investigación sobre el trabajo y el cuidado doméstico.

El análisis histórico sobre el servicio doméstico tiene una larga tradición. La investigación, sin embargo, ha sido planteada de forma mucho más sistemática desde la década de 1960 en adelante gracias al impulso dado por los historiadores sociales que enfocaron su atención sobre la historia de la familia, los historiadores demográficos y (particularmente desde la década de 1970) los historiadores e las historiadoras de las mujeres y del género. Durante un largo tiempo los académicos venían asumiendo que el servicio domestico (especialmente el interno) declinaría de forma paulatina y que incluso llegaría a desaparecer a causa de los procesos de modernización de las tareas en el hogar, del progreso social y del desarrollo del estado del bienestar. El renacer (completamente inesperado) del trabajo y los cuidados domésticos remunerados a lo largo de las últimas tres décadas ha dado pie a los sociólogos y a otros analistas sociales a prestar atención sobre el tema, abriendo nuevas oportunidades para el diálogo entre historiadores y otros científicos sociales. Este artículo trata de plantear una revisión de la investigación que se ha desarrollado en los temas anteriormente mencionados desde un nivel global, aunque con un enfoque fundamental sobre el espacio europeo y las que fueron colonias dependientes de las potencias europeas, a lo largo de los últimos cincuenta años, ilustrando las diferentes aproximaciones y sus resultados.

Traducción: Vicent Sanz Rozalén 